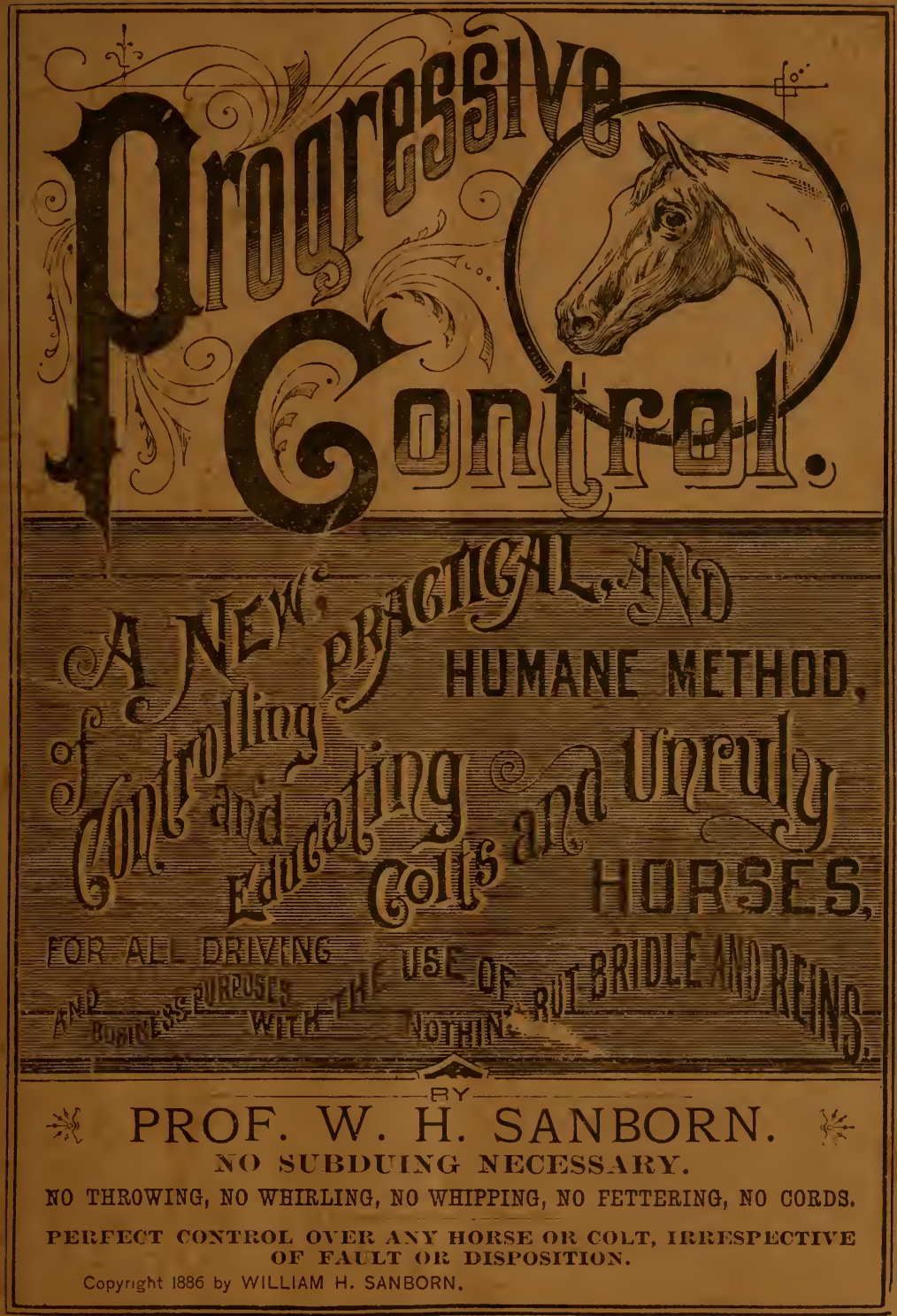


1- 


\section{PROGRESSIVE CONTROL}

OVER

\section{COLTS AND HORSES.}

PRACTICAL INSTRUCTIONS IN CONTROLLING AND EDUCATING THE COLT AND HORSE.

\section{BY PROFESSOR IT. H. SANBORN.}

\section{Ellustrated.}

Copies of this Book can be obtained by sending 50 cents, in registered letter, or postal note, to J. A. CUMMINGS \& CO, 252 Washington St., Boston, Mass. 

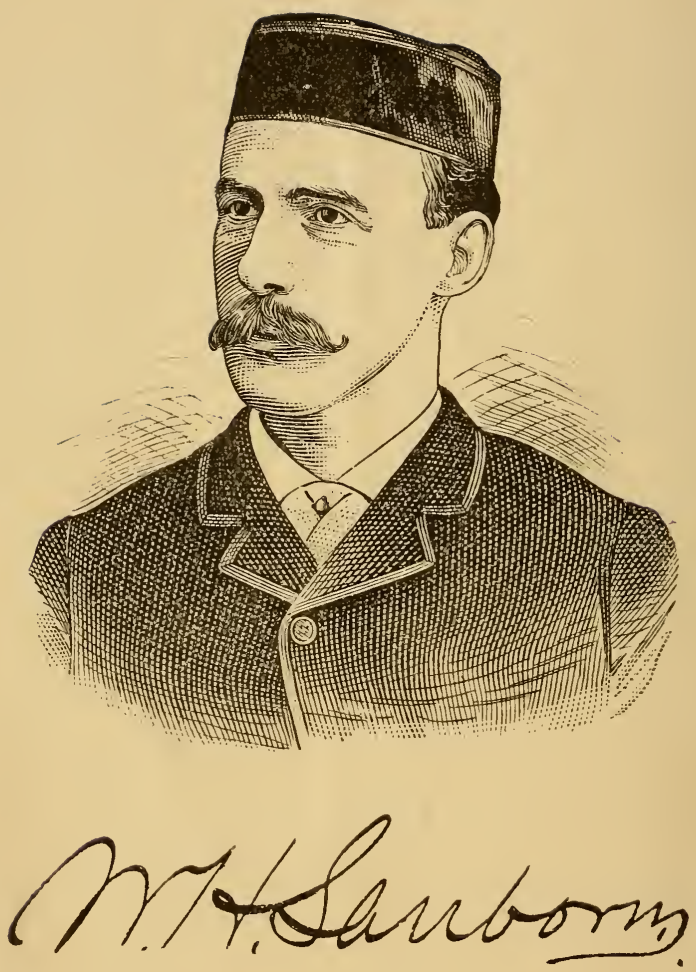


\section{PREFACE.}

In this rolume $I$ have endeavored to introduce to the farmers and horsemen of the United States a method, by the use of which they would be enabled to control and educate their colts and horses by appealing to the intelligence of the animal, instead of subduing and torturing them into submission, as was the result of every war-bridle system ever introduced. I will not attempt to disparage the methods taught by others : for when we consider that there is not one unruly horse to-day where a dozen existed twenty years ago, we must give them all, from Rarey down, a fair share of the credit for the result; for the introduction of their systems was the means of making useful and valuable many horses that otherwise would have been worthless. The war-bridle or rope systems, together with their accompanying methods of throwing, whirling and fettering, though all right in their day and the best then known, are too complicated and require too great an exertion to be used by any but an experienced horseman. These methods are too harsh, also, and leare the animal's mouth lacerated and sore, his muscles strained and his body bruised; in fact, the horse is punished after he has obeyed, which is torture and should be avoided in order to get the best results. Another objection is, that the use of the rope system does not get the colt or horse under control of the bit and reins where he belongs, and without which no colt or horse is properly educated. Then, too, the constant selection of the most intelligent and best developed horses and mares from which to breed, has produced a better colt mentally as well as physically; and the colt of to-day being nervous, sensitive, intelligent, and possessing a strong mind and great will power, will fight out to the bitter end any system or appliance that is calculated to torture him into submission; consequently there is need of an improver 
method of controlling and educating colts and horses; one in which there is no torture, and which will enable men to get that "obedience to authority," or acknowledgement of superiority, which is necessary before a man can educate his horse or a parent can govern his child, without crushing out the courage and will power which are the best attributes of the horse, but, rather, controlling and directing them into channels of usefulness.

What farmers and horsemen have needed and do need, in the education of their colts and horses, is a method of control, without harshness, which will apply to every horse or colt, irrespective of disposition, and a system or set of rules which will guide them in the education of every colt or horse regardless of fault.

Men have for centuries had but two appliances for controlling their colts and horses, viz. : the ordinary bridle and the various forms of the war-bridle. The ordinary bridle never was proper control over any horse or colt, for, with the bit sliding back and forth through his mouth and working on the lower jaw, which is a movable part of the head, he was enabled to toss his head into the air, double his chin to his breast, turn his head from side to side, look back at his drirer and ask him when he thought of starting. The war-bridle never was proper control for the reasons I have stated; besides which, by its use no colt or horse could be put through the evolutions necessary to educate him.

I have aimed in this volume, to explain to its reaclers in as concise language as possible, the different methods by which, with the use of a bridle like mine, the education of the colt can be brought to a state of perfection and the majority of unruly horses educated out of their habits. I trust that this little book will be read and studied, and the directions herein given be followed with pleasure and profit to all. 


\section{CONTENTS.}

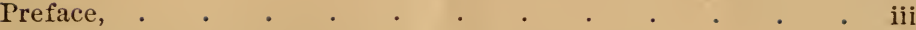

External parts of the horse, . . . . . . . . . viii

Introduction,.$\quad \cdot \quad \cdot \quad \cdot \quad \cdot \quad \cdot \quad \cdot \quad \cdot \quad \cdot \quad \cdot \quad \cdot 1$

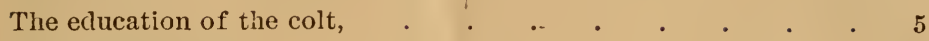

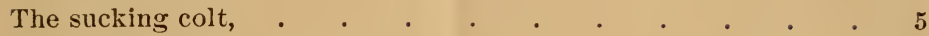

Halter-breaking the colt, . $\quad$. $\quad$. . . . . . 5

Instructions for making bridle, reins, etc., . . . . . . 8

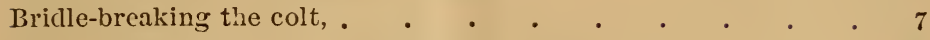

The "controlling touch" explained in Lesson III., . . . 11

To remove the halter after bridling, . . . . . . 11

To educate the colt or horse to back at the head, . . . . 13

To educate the colt to allow his body to be handled, . . . 15

To educate the colt to be shod, . . . . . . . 18

To educate the colt to start at the cluck and stop at the word

"whoa," . . . . . . . . . . . 19

Introducing the harness to the colt, . . . . . . 21

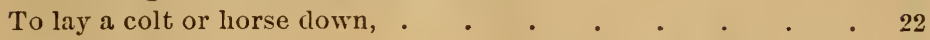

Bitting a colt, . . . . . . . . . . . 23

To educate the colt to the breast-plate, . . . . . . 24

To get the colt under control of the reins, . . . . . 25

To educate the colt to back by the reins, . . . . . $\quad$. 29

To educate the colt to stand at the word "whoa," . . . 31

To educate the colt to the shafts and properly shaft him, . . 31

Driving the colt to a vehicle, . . . . . . . . 34

Hints on driving colts and horses and making them "waywise," 36

Open bridles for colts and horses, . . . . . . . . 37

Care of colts' and horses' teeth, . . . . . . . . . $\quad$. 38

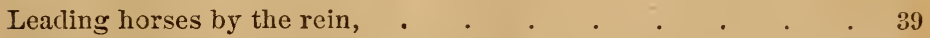

Concave roof in the horse's mouth, . . . . . . 40

Jerking on the reins, . . . . . . . . . 40

Approaching an unruly horse, . . . . . . . . . 40

Mesmerizing horses, . . . . . . . . . 41

To give the colt a good carriage of the tail, . . . . . 41

Rule for hitching to and unhitching from the rehicle, . • . 42 
Bits, • . . . . . . . . . . . . . . . 42

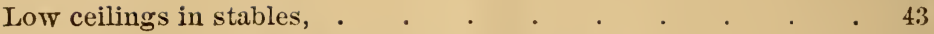

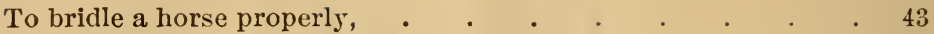

To compel any horse to get up when clown, . . . . . . . 43

To ecucate a horse to stand on the strect, . . . . . . . . . 43

The education of unruly horses, . . . . . . . . . . 45

Rule to be observed in educating every liorse, _ . . . . . . 49

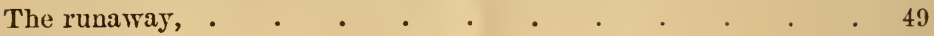

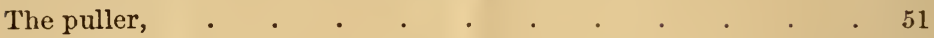

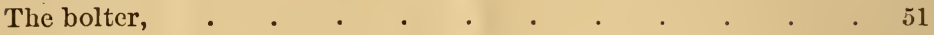

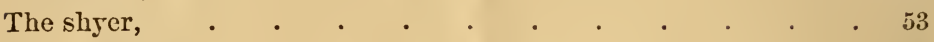

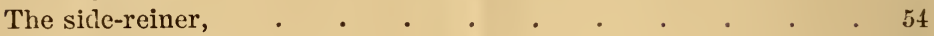

The balky horse, . . . . . . . . . . . 5

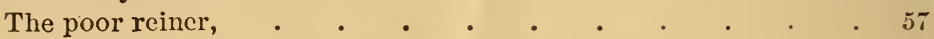

The horse afraid of locomotives, umbrellas, etc., . . 57

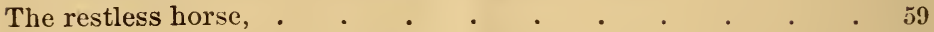

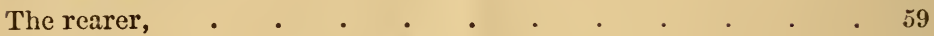

To prevent a trotter from breaking, . . . . . . . . 60

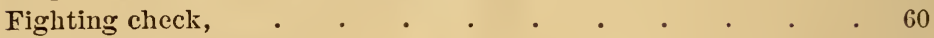

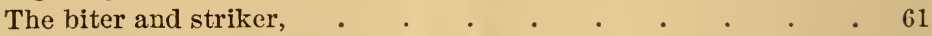

The stallion unruly "in stud," . . . . . . . . . . . . . 61

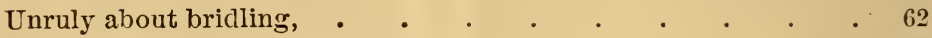

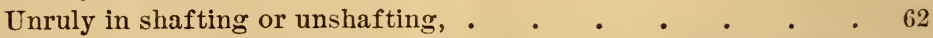

To control for clipping, castrating, bathing sores, sewing wouncls, cleaning sheath, milking out, cruppering, harnessing, unhar-

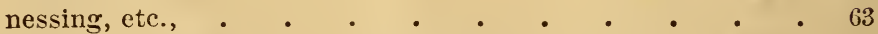

Instructions to blacksmiths for controlling colts and horses while shocing, . • . . . . . . . . . 63

To cure a switcher without cutting the tail, . . . . . 65

Simple method to break a halter-puller, . . . . . . . 65

To prevent a horse getting cast in the stall, . . . . . . 66

To prevent horses from nipping or tearing blankets, . . . 66

The breachy horse, • . . . . . . . . . . . . . 66

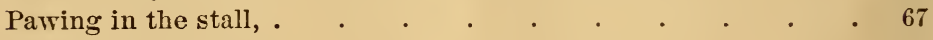

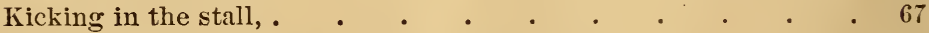

Crowding and kicking when entering the stall, . . . . . $\quad$. 67

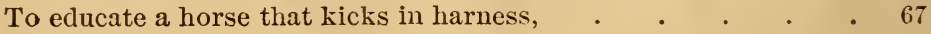

Conclusion, . $\quad . \quad$. . . . . . . . . . 71

"A bad penny always returns," . . . . . . . . . . . . 72

Treatment of diseases, . . . . . . . . . . . . 73

Testimonials, , , , , , , , , . 74 


\section{ILIUSTRATIONS.}

FIG.

PAGE

1. External parts of the horse, . . . . . . . riii

2. Bridle, reins, bit, etc., necessary for control and handling, . 8

3. Position for controlling and handling at the head, $\quad$. 9

4. Position for backing the colt or horse, . . . . . 13

5. Position for controlling with one hand, and holding reins when moving colt or horse about, . . . . . 15

6. $\{$ Positions for educating colt to pick up his hind feet and

7. $\{$ controlling kickers for shoeing, etc., . . . 18,19

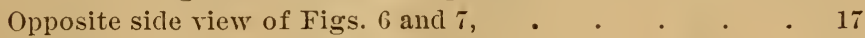

8. Position for laying colt or horse down, . . . . . . 22

9. Bridle, reins, thong for checking, reining-rings and safetyrein adjusted for giving reining lessons, . . . . . 25

10. Position of trainer in beginning to rein the colt and to propel a horse to the front by tossing the safety-rein, . $\quad 26$

11. Position for shafting as in Lesson XIII., • • • . 32

12. Arrangement of reins for driving until thoroughly educated. 35 


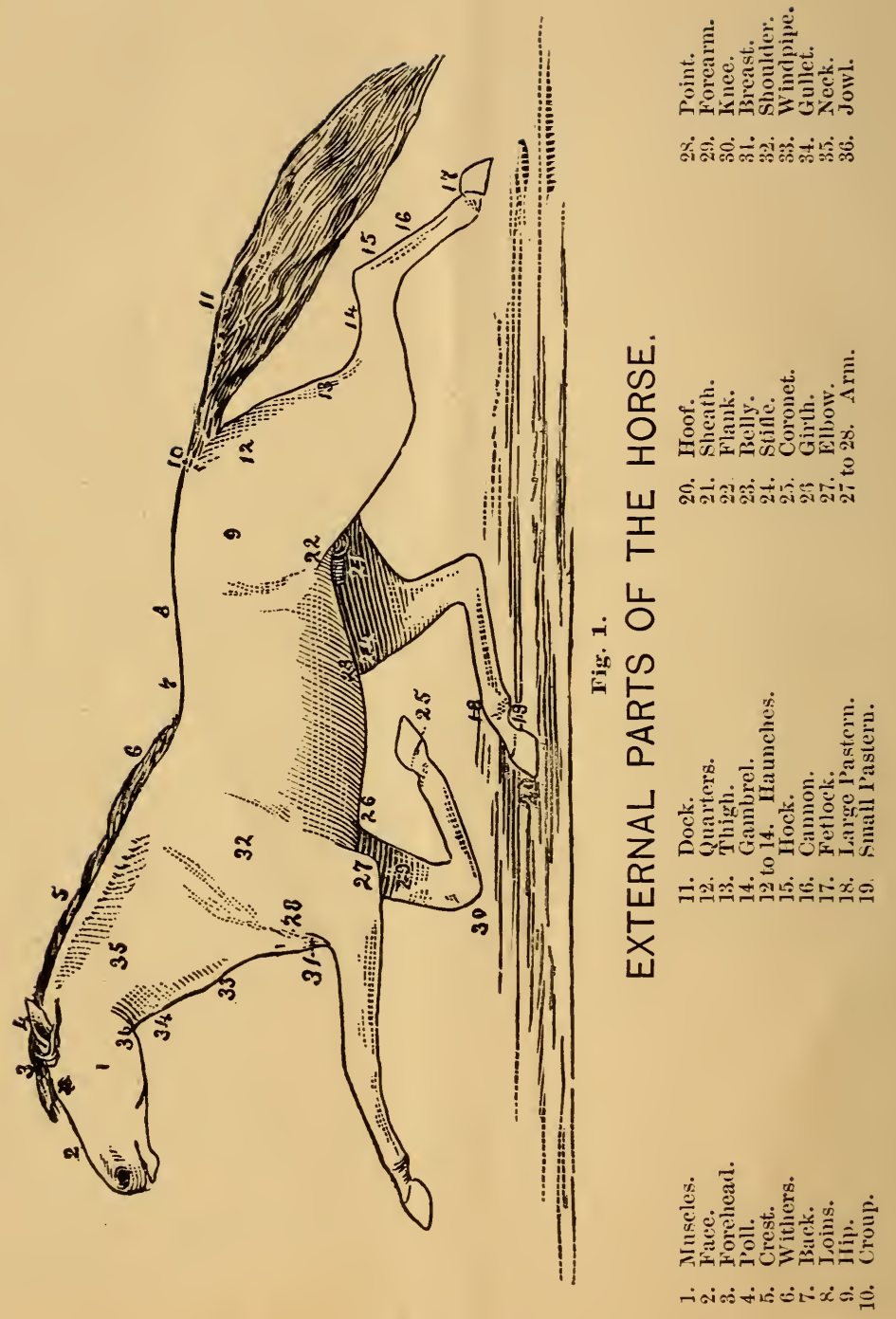




\section{Progressive Control over Colts and Horses.}

\section{INTRODUCTORY.}

Control over the horse simply means an acknowledgment on the part of the horse that you are his superior, or master. This acknowledgment can be obtained just as well by requiring him to perform several little acts, each of which he will object to do, viz. : Making him put and hold his nose against the side of the stable, hold his nose in and against the corners of the stable and against harnesses, robes, umbrellas, etc., by touching him ahout in different directions, changing directions quickly, by handling him head and foot together and leading hin about by the ears, nose, lower lip, and jowl, as by jerking him about with the war-bridle, or cords, and throwing or whipping him; and the horse's respect for you will be in proportion to the ease with which he sees that you are able to make him do these things. Besides, while the result is control over your horse hy appealing to his intelligence, it is educational also, because he may be called upon in the future to do the very things you have asked him to do while gaining control ; whereas, if you have used the war-bridle, thrown him or whipped him into submission, you have simply tanght him to fear you and his obedience is the result of that fear.

Patience is of great importance in the education of the colt or horse. Don't take it for granted that he knows intuitively what is wanted of him and understands the word of command, and fly into a passion because he doesn't happen to obey ; but, rather attribute his seeming stubbornness or disobedience to his not knowing what is wanted of him, and explain to him more carefully. 
The only way in which you can teach the horse what is wanted of him, is to put him through the motion necessary to explain; and that is where my bridle method of handling is superior to all others, in that the colt or horse must do as you wish him to, thus making it an easy matter to explain to and teach him.

Be careful to hold your temper. If, while handling a colt or horse, you feel your temper rise, put him in a stall, wrap your head in bandages dipped in ice-water and sit in the shade until you cool off. Then go back to your colt, beg his pardon and proceed with his education. An angry man is not in a fit condition to handle a horse.

Educate your colts and horses in the barn or yard. Have no one else about and drive out logs and fowls. If visitors come in put up your colt. You cannot visit and educate a colt successfully at the same time. The colt needs all of your attention and you need the colt's, in order to obtain good results, until his education is finished.

Never attempt to educate a colt when he is weary. You cannot make the right impression on a weary mind. When the horse shows the least sign of weariness let him rest.

Feed better when handling the colt than ever before. The extra strain on his system demands more food; besides, you want to keep up his spirit and will-power so you can control and educate it. A full stomach tends to make man or beast contented. If I wanted to borrow five dollar's, I would "strike my man" just after dinner.

Watch your colt carefully, when handling him, for the first sign of obedience, and be always ready to yield to him or remove whatever force you may be using at the moment he shows a willingness to obey. In this manner only can you explain to him that he has obeyed. The mistake is too often made of punishing the horse past the point of obedience, which only confuses him and makes work for yourself.

Your success will also depend on a careful watch for any sign which will indicate disobedience and your ability to "get 
there" just before your horse does. Whatever correction you use, the nearer you can bring it to the thought of disobedience the more effective it will be, and the nearer you can bring the removal of the correction to the thought of obedience the quicker you can appeal to the intelligence of the horse.

Speak in a quiet, firm tone when commanding the horse. He has a quick ear. Shouting is unnecessary and only tends to arouse and irritate him. Speak the word of command but once, and teach the horse that he must obey the one word. The simpler the language used the more readily will he understand. The use of too many words serves to confuse, besides, it makes the horse similar to a child that is being constantly talked to by its parents: he is soon unable to know when you are in earnest.

I am not a believer in "kindness" to the horse, as that term is generally understood. By "kindness" is usually meant a constant coaxing, caressing and feeding of apples and sugar on every occasion, with no control or discipline connected, and with no definite purpose in view. No method has created so many balkers, bolters, biters, kickers, or runaways, or been so productive of destruction to life, limb and property, as this foolish cossetting. "Kindness to the horse" should mean a firm discipline, the absence of abuse in controlling and educating, and a system of reward in the form of a caress, an encouraging work or a bit of apple or choice morsel, only when he has obeyed and never when he is disobedient.

The spirit of rivalry as to who shall produce the fastest yearling or two-year-old will lead the horsemen of our country into excesses in early training, and, ultimately, be the means of decreasing the strength and endurance of the coming generations of colts. The soft, yielding muscles, joints and tendens of the undereloped colt are not in a condition to stand the strain attendant on the severe early training necessary to fit for a race; much less are the sheaths, through which the muscles play, firm enongh to hold the expansion of the bundles of muscles as they are gathered for a desperate move, and, in a 
few years, we will see stocked legs, enlarged joints, tendons, etc., and these blemishes will be attributed to a recent injury, when such things do not develop in a short time.

When horsemen stop and consider that the present state of perfection of the horse, and the very ability of their colts to trot so fast, are qualities inherited from sires and dams that were not trained young; and that, when these over-trained and over-exerted colts, weakened in body and mind by excessive work, are coupled, they will transmit their infirmities to their progeny thus in a few years producing a race of weaklings, then will the change come, and I predict in the course of ten years a complete revolution in the prevailing ideas concerning early training. 


\section{THE EDUCATION OF THE COLT.}

\section{LESGON I. \\ THE "SUCKER."}

Before the colt is a month old, it will be a good plan to get hold of him, pass the left hand and arm under and around his neck, and, with the right arm over his shoulder, grasp his off fore leg in the right hand and hold him close to you until he ceases his struggles, when he should be patted and rubbed until he shows no fear. 'This should be repeated until he will submit to be handled without objection. As soon as he will eat, reward him with a bit of apple when he is obedient to your wishes.

\section{LESSON II.}

\section{HALTER BIEAKING.}

When you wish to halter-break a colt, take a common web or strap halter that fits well, and to the ring under the chin fasten two pieces of old reins, or ropes the size of a bed-cord, long enough for the colt to tread on with his fore feet when the halter is on. 'Then take the halter, and a generous supply of pieces of apples in a small pail, and introduce yourself quietly into the colt's pen. Stand still until he has looked you over and formed some idea of what you are; then approach him quietly, holding the temptation out in your hand. Be patient, and in a short time he will take the bait. Repeat this until you are able to touch him with the other hand, when you 
will quietly scratch and rub his neck, gradually working your hand towards his ears and feeding him with the other hand. He will soon allow you to work about his head and ears, when you can put the hand with the bait through the nose-piece of the halter from the bottom up, and, as he takes the bait, slip the halter up over his nose with the other hand and fasten it on. Make no sudden moves with the body or hands. If you fail to get the halter on at the first attempt, be patient and try again. Don't be in a hurry and try to force matters. Don't try to halter him if you haven't much time to spare. If he will eat your supply of apples without allowing himself to he haltered, leave him alone for an hour, then go and try again. In your absence he will at least have formed a favorable opinion of you, and will welcome your second coming. After getting the halter on, let him go with the reins trailing on the ground, and, by constant treading on them, he will halterbreak himself in about forty-eight hours so you can lead him anywhere. In most cases, if he is halter-broken in this manner, he will stand tied. If he does not, and you wish to teach him to stand tied, fasten about fifteen feet of clothes-line to the halter-ring, lead him to a post, put the rope about it, take hold of the free end and give a strong, steady pull. If he should slat or pull do not hold him hard, but ease away on your end until he stops pulling, when you will snub him up again and repeat until he gives to the halter. Then lead him about the barn and yard and repeat this lesson by putting the rope about a dozen different places and teaching him to stand at them all.

The old method of teaching colts to stand tied by tieing them to a post with a strong rope and letting them slat and pull until they were exhausted, has been the cause of more sparins, puffs, etc., in after years than anything else. Such things do not come in a short time, and, though usually attributed to some recent cause, are the result of an injury to the colt when his joints and tendons were undeveloped and unable to stand a severe strain. You should aroid, in every instance possible, 
"holding them to it," as the saying is, for it makes them frantic, and the well-bred colt of to-day represents too great a value for you to jeopardize his safety in that way.

It is advisable, when possible, to get your colt accustomed to be carded, and to allow his head, feet and tail to be handled while he is small and you are able to control him from superiority of strength. When he begins to eat, a few dollars judiciously expended in a variety of food will give him a good start in life, and when a well-fed colt has matured, his rugged appearance and strong frame will attest to the wise expenditure when young. A half-fed, stunted colt will carry with him through life that exhausted, anxious-for-a-holiday appearance borne by so many of the horses.

If colts could be reared on a hill-side they woula have a better constitution and wear longer than those grown on level land. Aside from the benefits derived from the better quality of upland pasturage, in travelling about on the hill-side every muscle would be called into action and the result would be a well-developed and strong-limbed horse.

\section{LESSON III.}

BRIDLE-BREAKING THE COLT.

Before putting on the bridle, take the colt by the halter, and with your left thumb, toich him up under the upper lip on the roof of his month. Any horse will open his mouth if you touch him there. Repeat this until he shows no objection and is educated to allow you to do it. Hang the bridle on the right thumb with the thumb in the center of the crown-piece. Lay the bit in the left hand between the first and second finger and forward of the thumb, with the thumb inside of the near bitring. Bring the bridle before the colt's face and carry the bit, held in the left hand, to his mouth. You will find that the bit now lies para.lel with his $\mathrm{li}_{\mathrm{i}}$ s and your thumb is in position to 


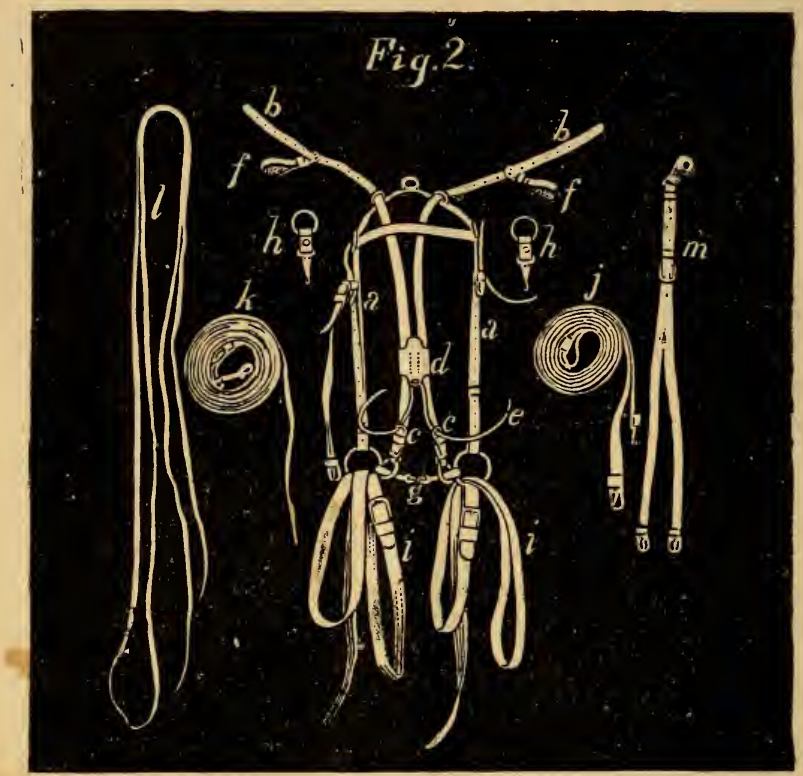

BRIDLE, REINS, ETC., NECESSARY FOR PERFECT CONTROL OVER THE HORSE.

$a a$. Bridle, constructed with long billets for the cheek-pieces, having but one buckle each, by which to adjust their length, which allows the bridle to be acljusted to any length of head. Any bridle will answer for grown horses, with over-diraws, etc., attached, as shown in the illustration.

$\ddot{b b}$. Over-draw straps, five-eighth inch wide and thirty-two inches long. Billets to be short as possible, with five-eighths rings (cc) sewed into the splices with the buckles.

cc. Rings on billets, to which the keeper $(d)$ is to be tied with the cord (e).

d. Keeper, to be made arljustable, snug as possible to the over-draws, with half inch leather block between them. The control is increased by pulling the keeper down and lessened by pushing it up.

$e$. Cord, running through two holes in lower end of keeper, and used to fasten keeper $(d)$ down to full control by putting cord $(e)$ through rings $(c c)$ and tieing in a knot across horse's nose.

ff. Loops, with buckles attached so they can be adjusted on the over-draws back of the crown-piece as may be required. The loops should be two inches in diameter and as close to the buckles as possible. In driving with the reins through the loops the control is increased by buckling them up on the over-clraws closer to the crown-piece, and diminished by buckling them away from the crown-piece.

g. Wilson, four-ring, double-joint, bit.

$h h$. Reining rings, attached close to snaps by a piece of leather and rivets between suaps and rings. These rings are snapped on to the buckles on the inner girth for the purpose of running the reins through when handling a colt or horse by the reins. They will be found to be much better than the thill-lugs for that purpose.

ii. Leaders, six feet long each.

$j$. Hand-pieces, buckled together, seren feet long each.

$k$. Safety-rein, fourteen feet long. Thicker towards the bit end, and snap attacheri.

l. Leather thong, fourteen fect long, used as a check. A small rope will answer as well.

$m$. Check extension, for use when colt or horse is educated and behaves well. 
touch him under his upper lip. You will now touch him under his upper lip with your thumb; his mouth will open, when you will raise the bridle with the right hand and carry the bit up into his mouth. Then run the left hand under the bridle and gather the fore-top in the left hand. Tuck the off ear under the crown-piece and into place with the right thumb; then, still holding the fore-top in the left hand, change the right hand to the near side of the crown-piece and tuck the near ear into

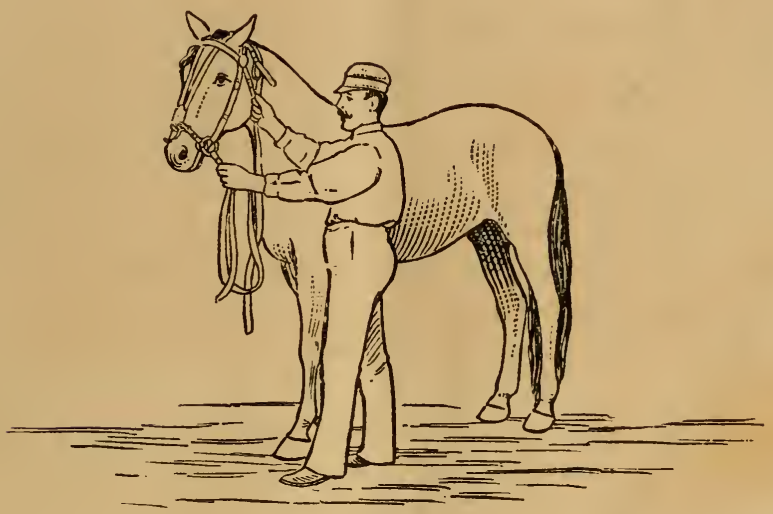

Fig. 3.

POSITIOX FOZ CONTROLLIXG AND HANDLING AT TIE HEAD.

Arrangement of off leacler through loop on off sicle being shown on page $i \tau$.

The "controlling touch" is given by pressing downwarl with the right hancl and immerliately slacking away, at the same time bearing steadily on the near leatler with the e e ert hant.

place with the right thumb. Then pull the fore-top down with the left hand, and the bridle is on properly. Then buckle the throat-latch pretty snug for all stable handling (but do not forget to drive always with a loose throat-latch so as to enable the horse to breath easily). Then adjust the cheek-pieces so that the bit will lay just to the corners of the mouth; having them too snug will irritate the colt or horse. Then pull the keeper down on the colt's nose until the bit lays up against the 
roof of the mouth. It must not be very sung to the roof unless you have a bad case and want extreme control. Take your thumb and press the lips outward away from the gums so as to let the bit lay to the roof. Fasten the keeper in place with the thong or cord which runs through the holes on the lower end of the keeper, by putting the ends of the thong through the rings on the over-draws near the bit and tying them across the nose. Then take hold of the ends of the over-draws, back of the crown-piece, draw them up snug and buckle the loops up close to the rings on the crown-piece through which the over-draws run. Now put the off leader through the loop on the off over-draw and toss it over the neck to the near side. The bridle is now arranged for control. Take your position as in fig. 3, by grasping the off leader in the right hand and taking a firm hold of the near leader, close to the bit, with the left hand. Keep a steady downward pull on the near leader and press downward and forward on the off leader, at the same time stepping backward away from the colt. Repeat this, stepping backward each time, and take the colt around in a circle first, then gradually work him out of the circle into a straight line. Remember that you keep a steady pull on the near leader only, and accompany it with a downward tonch over the neck on the off leader, and when the colt answers to it and steps towards you, immediately slack away with the right hand. Your object in touching down on the off leader is to cause the center of the bit to press against the center of the roof of his mouth, and when the colt moves towards you, by slacking away on the off leader you remove the pressure of the bit, the colt soon understands it and will answer to it readily. When he readily answers to the touch over the neck and will come to the front in answer to it, lead him about the stable, occasionally touching down ou the off leader, and then make him put his nose against the side of the stable. If he refuses, touch downward on the off leader and persist until you succeed with him. The downward touch over the back of the neck with the off leader, which causes 
the center of the bit to tonch the roof of the mouth, is called and wiil hereafter be known and spoken of as the "ControtLING Toccu." 'Then lead the colt into every part of the stable; after which, lead him into the yard; find every place possible where he will refuse to go and compel him to go by the "controlling touch." Hang up umbrellas, robes, etc., and compel him to go to them. In leading him about, change to the off side, reverse the leaders by putting the near one through the loop on the near over-draw, toss it over the neck, let the off leader hang from the bit, take hold of the off leader in the right hand near the bit, the near leader in the left hand (as in fig. 3 reversed), and give the "controlling touch" with the left hand. Make this a rule in the education of the colt, viz., to handle as much on one side as the other and educate both sides alike. If, when you give the "controlling touch" the colt or horse does not answer to it readily, it is becanse the roof of his mouth is concave and the bit cannot reach the center, in which case wind the center with copper wire and elevate it as much as possible. If when you give the "controlling touch" the colt will slat or pull, do not hold him firm, but ease away on the reins until he stops, when you will repeat the touch until he comes without resisting. This should be a rule in handling every horse.

It is advisable to bridle the colt orer the halter untii he will stand still to be bridled. By so aioing you hare the means of checking him if he attemps to get away or resists being bridled. After putting on the bridle, remove the halter by unbuckling the crown-piece of the halter, and, taking hold of the nose-piece, pull it down over the end of the nose, push it up into the mouth, over the bit and out of the mouth. Then adjust the bridle. If the halter does not unbuckle top of the neck, pass the crown-piece of the halter under the crown-piece of the bridle, over the ears and down to the nose. Remove the nosepiece of the halter first, then follow it with the crown-piece.

In order to properly educate the colt, it is essential that he should be bridle-handled in order to get him under control (for 
without control you cannot educate) ; get him acquainted with the bit and accustomed to answer to it in every direction. The elucation of the colt simply consists in putting him through certain motions and repeating this often enough to make a permanent impression on his mind as to what he must do in answer to each word of command. If you have a bridle of such construction, and a method of handling that will enable you to so perfectly control his movements that he can do nothing but what you wish him to, it will become an easy matter to educate him. But, if, when you attempt to lead or drive him to one place, he can, on account of poor control, go to several other places, you have failed to explain to him where you did want him to go; in fact, by his being able to go to the wrong place he is led to understand that it was the right placa, and your labor is more than doubled; for you will have to get that impression out of his mind before you can get the right one in, and his education becomes a difficult task.

Right here is where the benefits of my bridle and my method of handling it will be realized by those who have colts or horses to educate ; for, by its proper use, it is an utter impossibility for the colt or horse to do anything but what you want him to do.

The object in finding places to which he will refuse to go is to get him under perfect discipline and get him to thinking that he must go wherever you lead. When you get him to that point he is perfectly halter-broke and not before. Do not speak the word "come," or " here," to the colt when you are teaching him to lead, for by so doing he will counect the forward motion with those words, and when you start to teach him that a cluck means to go forward you will have to unteach him; whereas, if you start him with the cluck at first, by the time he is ready to drive he will understand that it means "go to the front." Teaching him to follow at the word "come" may be called an accomplishment, and such things should be reserved until tha business part of his education is finished. 


\section{LESSON IV.}

TO TEACH THE COLT TO BACK AT THE HEAI).

Put the bridle on for full control, that is, with the keeper fastened snugly down on the nose, the loops buckled close to the crown-piece, the off leader through off loop and tossed across the neck on to near side. Take position as in fig. 4 . Press backward with right hand just enough to hold the colt's

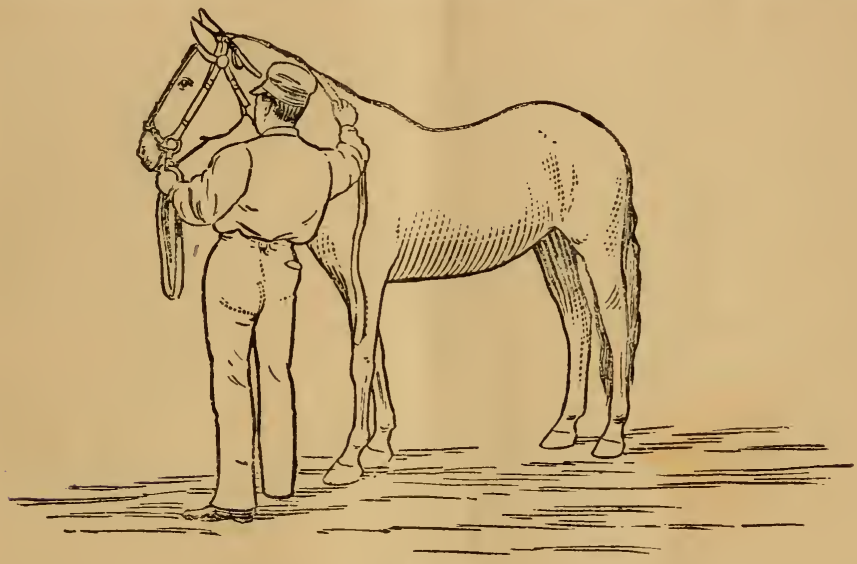

Fig. 4.

POSITION FOR BACKING COLT OR HORSE AT THE HEAD.

fore feet in one spot as nearly as possible and touch him under the chin with the near leader held in left hand. Touch him about to the right with the left hand, at the same time holding back on the off leader with the right haud. Work him about in a circle, gradually enlarging the circle, and you will soon have him backing in a straight line. When he steps back at the backward touch of the leaders, slack away immediately on the leaders. Then repeat the touch backward, slacking away on the leaders each time he yields to the bit. By doing this you explain to him that he has obeyed. When he understands 
that a backward pressure on the bit means to step back, tinen speak the word " back," accompanied with the pressure, and he will soon learn what the word means. Repeat this until he will back at the word alone. Now it is necessary to get him to refuse to back in order to make him a clisciplined backer. Pile some brush on the floor and back him towards it. He will probably refuse to back on to it. When he does, set heavily back on the off leader with a steady pull and set down heavily on the near leader. If he is very stubborn, throw the off leader over to the off side, pass it back of his fore legs, take the free end in your right hand and set heavily ahead on it, at the same time setting down on the near leader. This will back the most stubborn case. If, when you are touching the colt about to the right he should become stubboru, as they sometimes will, and allow you to put his head around to his off shoulder without moving his body, don't get angry and try to force him around, but lay your back against him just back of his near shoulder and take him about to the left, then change to the right and he will soon back.

Never speak a word to the colt when you are handling him, until you have taught him to go through the motion on the pressure of the reins or bit; because he knows nothing about the meaning of your language, and it only serves to take his attention to the sound of your roice and hinders your getting the desired motion. But when you have taught him the motion, then accompany it with the ror of command and he will soon connect the two and understand what the word means.

Backing is an unnatural motion with the horse and he must be taught it. The object in putting him into some position where he will refuse to back, after you have tanght him to back, is to convince him that he must back when you ask him to: and no horse is a perfect backer that has not refused to back and been forced to do it. The colt's seeming refusal to back, before he had learned the motion and what the word "back" meant, was not disobedience, because he did not 
yet understand what was wanted of him. If he won't refuse to back orer the brush, take him ont into the yard and back him into a soft spot; and don't fail to get him to refuse to back somewhere and compel him to back, for if you do not do this he will refuse in the future where it will trouble you, and it will be less work to handle him now while you are prepared. If he should get angry and slat, don't hold him firm, but ease away until he stops, then try him again. This method will not fail to teach any horse to back.

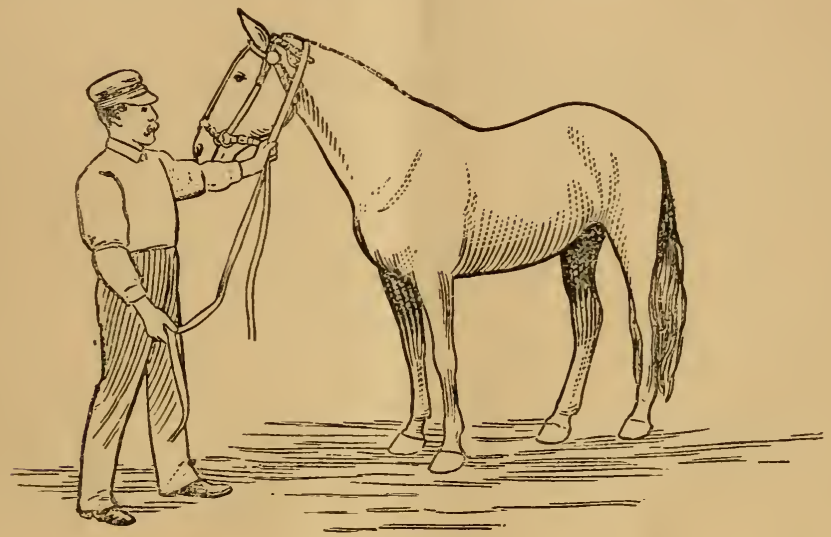

Fig. 5.

POSITION FOR COXTROLLING WITH ONE HAND AND IIOLDING REIXS WIIEN MOVING THE COLT OR HORSE ABOTT.

The "controlling touch" is given by touching downward on both reins.

\section{LESSON T.}

TO EDUCATE THE COLT TO ALLOW HIS BODY TO BE HANDLED, TO BE CARDED, ETC.

Put on the bridle for full control as described in Lesson III. Take a bag in the right hand and hold both reins at corner of jaw as in fig. 5 . Bring the bag to his nose with right hand. If he shows fear and tries to get away, give him the "controlling touch" and repeat it until he stands still. 
Play about his head and body with the bag until he will allow you to stand back the length of the leaders and throw it at him without moring. Then take a paper, umbrella, robe, harness, whip, etc., and do the same thing and repeat this lesson in the yard. This will not only educate him to these articles, but will teach him to control his nerves when he sees objects approach him suddenly.

Then handle his head thoroughly. Take hold of his near ear with the right hand and handle it thoroughly. If he objects, touch on the near leader with the left hand, which will cause the bit to touch the roof of his mouth and control him. Then lead him about by the ears, mane, foretop, nose, jaw and lower lip. Touch on near leader with left hand if he objects. Put right arm over his head and teach him to hold his head down by pressing down with right arm and touching down on near leader with left hand, and allow your arm to slip over his ears and back again. Then handle him all about his body with your right hand and handle his tail by grasping it firmly in right hand and working it in every direction; then toss it well up over the back several times. If, when handling the tail, he steps away from you, step back to his head, place him back from where he moved, touch down on both reins and say "whoa." Repeat this patiently as many times as is necessary to make him understand what you want. Handle the underside of the tail well with the hand. If this is thoroughly done he will not scringe or kick when being cruppered or uncruppered. Hold the leaders in your left hand and give him the "controlling touch" in case he objects.

Take a pole like a sled-stake and bring it to his head until he gets acquainted with it. Then rub him all about his body and legs. Pry between his legs and teach him to ease up on the pressure. Thump him gently all orer his body, and especially about his flanks and haunches where the cross-bar would strike if the breeching should break. Lead him about the floor with the pole between his legs and teach him to step over it and allow it to rub against his legs. Play the pole 
along his side where the shafts will come and repeat these lessons until he will stand on a halter and allow it. Give him the "controlling touch" if he objects, and say "whoa."

Teach him to pick up his fore foot by passing the near leader under the fetlock and lifting on it with the free end of the leader in the right hand. He will soon learn that picking up his foot removes the pressure of the bit in the roof of his mouth. Then take up the foot in a loop of the off leader, hold

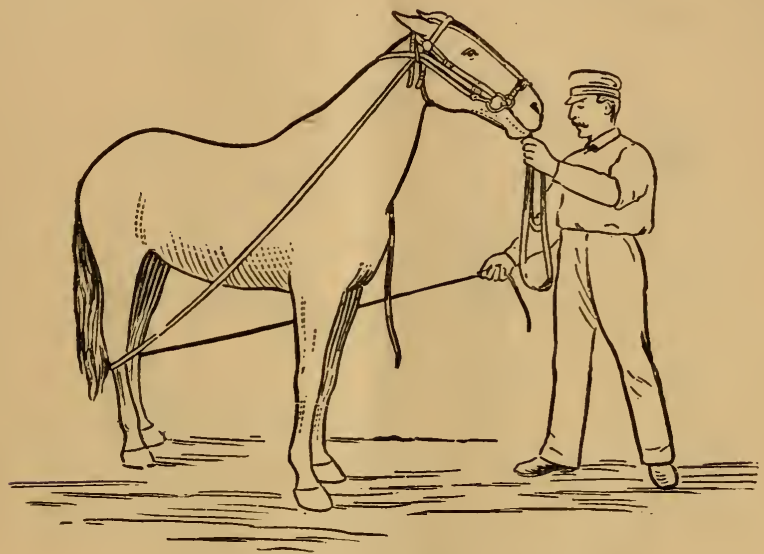

OPPOSITE SIDE VIEW OF FIGS. 6 AND 7.

Showing safety rein running from the bit-ring througl the loop on the off overdraw, as it should be on opposite sides of Figs. 6 and 7 . Also, showing off leader running from the bit-ring through the loop and over the neck as it should be in Figs. 3, 4, 5 and 11.

it in the left hand and pound and rub on it with a hammer or piece of hard wood. Teach him to hold his foot up until you are ready to let it go. Pass the near leader under his near fore leg, and by lifting on the leader raise his leg up and teach him to hold it on the rein. Then if he gets his leg over the halter he will hold it there until help comes. 
TO EDUCATE THE COLT TO BE SHOD.

To teach him to lift his hind foot, snap the safety-rein on the off bit-ring, run it through the loop on the off orer-draw and toss it about his heels as in fig. 6. If he is inclined to kick at it, let him. He will soon see the folly of it. When he will not resist the rein about his heels, toss it up over his back, pass the free end inside of his near hind leg, take hold of the end with the right hand and let it drop under his fetlock, as in

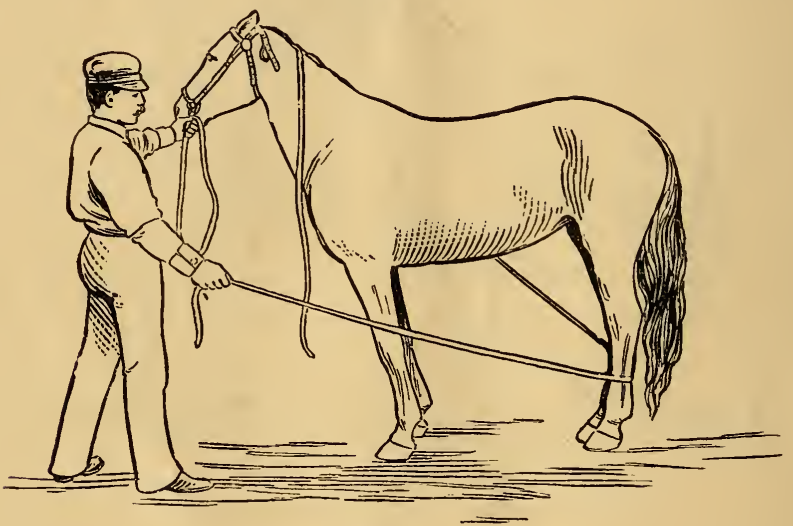

Fig. 6.

POSITION FOR CONTROLLING COLTS' AND KICKERS' HEELS.

See illustration of opposite side on page 17 .

fig. 7. Educate him to lift his foot by drawing forward on the safety-rein with the right hand. When he will lift his foot, take the foot in a loop of the safety-rein with the right hand, at the same time taking both the leaders in the left. Lift his foot in the loop, work it up and down, in and out, forward and back and, finally, place it on your left knee, pound and rub it with a hammer and teach him to hold it until you choose to let it go. If he undertakes to kick, hang hold of the free end of the safety-rein and let him kick in the slack. 
He will quit it. If he is simply restless and tries to take away his foot, give him the "controlling touch" with the near leader.

Remember and repeat every lesson on the opposite side by putting the near leader through the loop on the near over-draw, tossing it over the neck and giving the "controlling touch" with the left hand. Handle every part of your colt thoroughly and educate every joint. Educating one part of a horse doesn't educate the other parts.

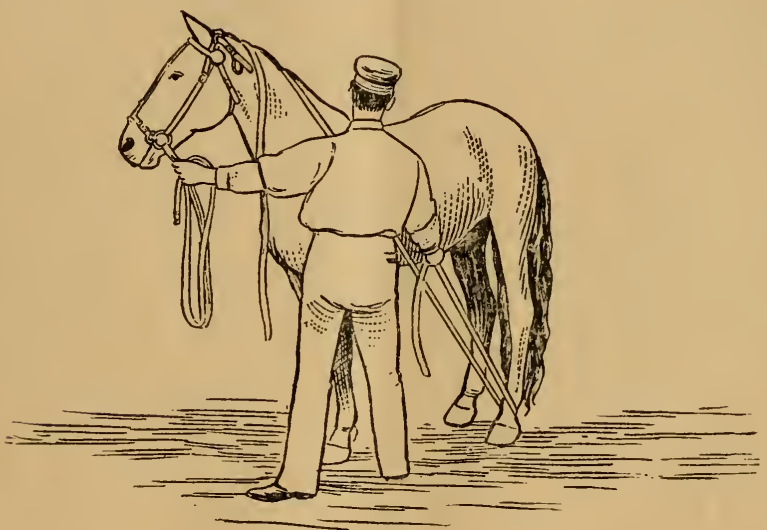

Fig. 7.

POSITION FOR EDUCATING THE COLT TO PICK UP HIS IIIND FEET, AND CONTROLLING A LICKER FOR SHOEING, ETC.

TO EDUCATE THE COLT TO START AT THE "CLUCK" AND TAP OF THE WHIP, AND TO STOP AT THE WORD "WHOA."

Put on bridle for full control and take position as in fig. 5 , holding both leaders in left hand at corner of jaw. Take the whip in right hand. Touch him to the front with the off leader over the neck, at the same time cluck, and follow the cluck with a tap of the whip on his back forward of his hips. Let him go a short distance, say "whoa," and stop him by pressing downward and backward on both leaders. Repeat this 
antil he has learned to start at the cluck without a touch on the leaders, and as you see that he understands the signal to start, gradually work away from him on the leaders, letting lim circle around you to the left; and when you have reached the end of the leaders, as he is circling about you, work slowly closer to him and touch backward on the near leader until he understands that a pull on that side of the bit means for him to turn to the left when the leader is held along his near sicle. Then reverse your leaders and do the same on the off side; gradually working up to him and touching on the off leader antil he learns that it means for him to turn to the right. He has now learned the meaning of a pressure on either side of the bit and is a "reiner" as far as his head is concernec. Then take position as in fig. 3 , touch him to the front with the off leader, at the same time clucking to him, and when he has stepped one step say " whoa," at the same time touching straight down on both leaders; and teach him to step one foot at a time and stop when he is commanded to do so. Repeat this lesson three or four times for five minutes each until he will step and stop when commanded.

The whip should be used simply to get motion to the front when the horse does not respond sufficiently to the word, and merer as a punishment, and no horse is properly educated or safe to drive until he is under such control of the whip that he will respond to it and go to the front every time it is applied properly. The colt should be taught to not fear the sight or sound of a whip. This can be accomplished by holding both leaders in the left hand, as in fig. 5, playing and flourishing the whip all about the colt and giving him the "controlling touch" if he objects to it. Do not strike a horse back of his loins with a whip, for it tends to make switchers and kickers, also to break his gait when trotting, as he will rise behind to resist the whip if applied back of his loins. On the shoulder is the best place to apply the whip, and it should be used with a smart tap, just sufficient to get the required motion necessary to enable you to guide him. You have the right to use the 
whip suficiently severe to put him to the front, and no more, for your or your family's safety will often depend on the horse's obedience to the whip in that respect.

Do not work your colts in a circle too long nor too fast at $x$ time, as it tends to injure the brain and eyesight. The old practice of "lungeing" is practically given up by thinking horsemen. The object in teaching the colt to step one foot at a time and then stop, is two-fold. First, your design should be to keep him impressed with the iclea of your superiority over him, and compelling him to go through such little maneuvers not only holds but increases your control, and helps to bring his mind under discipline. Second, it is educational. He will be required at some time in the future to step ahead a little and then stop, and now is the time to educate him to do it. In educating the colt you should exercise your ingenuity and teach him to do everything possible that he will be required to do in the future; put him in all possible positions in complication with poles, ropes, straps, boxes, brush, etc., and teach him to extricate himself with ease and intelligence.

\section{LESSON VI.}

INTRODLCING THE HARNESS TO THE COLT.

Have bridle on for full control and take position as in fig. 5 , with saddle part of the harness in right hand. Quietly raise the harness orer the left arm and bring it to the colt's face. Play it about his face until he doesn't notice it, then pass it over his head and rub him all over his body and legs with it. Then toss it on him, gently at first, then more violently until he will allow it to be tossed in the air and alight on him anywhere. If he objects correct him with the "controlling touch" and say "whoa." Finally, place the harness on him, buckle the girths, place the crupper carefully uncler his tail and buckle it. The girths should not be buckled ton 
tightly at first, and all cruppers should be made with buckles, not only for convenience and safety, but also because it will admit of cruppering without getting your hands and person soiled by contact with a foul tail, and avoid the trouble of tucking a heary tail through a small crupper.

\section{LESSON VII.}

\section{LAYING THE COLT OR HORSE DOWN.}

Put on bridle, have the keeper down to full control and the loops buckled close to the crown-piece. Have both leaders

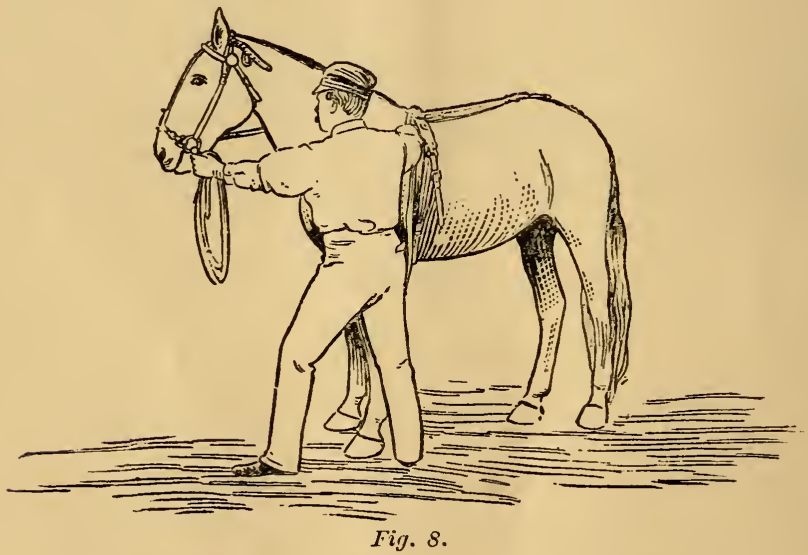

POSITION FOR LAYIXG A COLT OR HORSE DOWY.

hanging from bit-rings. Put on saddle, back-strap and crupper. Snap one of the reining-rings to the off terret-ring or to the water-hook. Put the off leader through the reining-ring. Take up near fore foot either to a ring on the girth or with a knee-strap. Stand on near side by the shoulder. Grasp near leader with left hand close to the bit and take end of off leader in right hand as in fig. 8. Cluck to him and start him 
to the left. When he steps with the off fore foot, hold him and he will come to his knee. 'Then toss his head to the right with the left hand, at the same time pulling forward on the off leader with the right hand. You will pull his nose around to his off shoulder and he will lie over on his near side. Then tie a knot in the off leader close to the reining-ring and you have him fast. Then handle him all over with a pole, harness, etc., and teach him to lie quietly. Soon you can release his head and by holding it down keep him from rising. When he does not resist, caress him and give him a bite of apple when he arises.

It is a good idea to lay a colt down a few times and pole him about his body and legs so as to teach him to lie quietly in case he ever gets down by accident. Besides this, it adds to your control over him and gives him an idea of your superiority. If when he comes to his knee, he should struggle, don't hold him to it but let him come up and try again. Holding him to it only tends to make him frantic; and by trying again you explain to him what you want him to do.

\section{LESSON VIII.}

BITTING THE COLT.

Have the saddle on as in the preceding lesson. Put the keeper up on the over-draws just below the eyes. Then take a pliable rope (cotton is best) size of a clothes line and about eighteen feet long, tie one end into the thill-lug on near side, pass the other end through the near bit ring, then through the loop on the near over-clraw, then under the water book, then through loop on off over-draw, then through off bit-ring and to thill-lug on off side. Draw the rope snug, tie into the thill- 
lug aad let the colt work around on the stable floor or ia the yard for not more than half an hour. Don't bit too tight the first time. When you finish his next lesson bit a little tighter and increase it after each lesson until you get the desired result. You can get the same result by using any bridle or bit and running the rope through the bit-ring, then through the checkloop on the throat-latch.

I recognize but two objects to be attained by bitting the colt, viz. : to teach him to stand under the check and to bear a reasonable pressure on the bit when driving. Every other desired result can be obtained by bridle-handling and continuing his education as described in this book.

\section{LESSON IX.}

PUTTING ON THE BREAST-PLATE.

Before you begin to educate the colt to be driven with reins, put on the breast-plate and tie the tugs into the breeching so that he will feel the pressure of the breeching and breast-plate every time he steps; and the tugs should be tightened from time to time, as he gets accustomed to it, until finally they are so tight that he will be pulling more than he will be required to pull if he were hitched into a single vehicle. They should also be tight when he is educated to back by the reins; then he will not refuse to back in the breeching to a vehicle.

Some colts are broke to collar and hames with another horse, and when asked to go single in a breast-plate they will try to step over and out of it. If the breast-plate were put on them, the tugs tied in the breeching and they were worked about on the floor for twenty minutes they would give no trouble. 


\section{LESSON X.}

TO GET THE COLT LNDER CONTROL OF THE REINS.

Put on bridle and have the keeper well down, though not quite at full control. Buckle the loops on orer-draws about three inches from crown-piece. Lay the near loop on the side of the colt's neck just half way between the throat-latch and the zoots of the mane. Run the near leader through the near

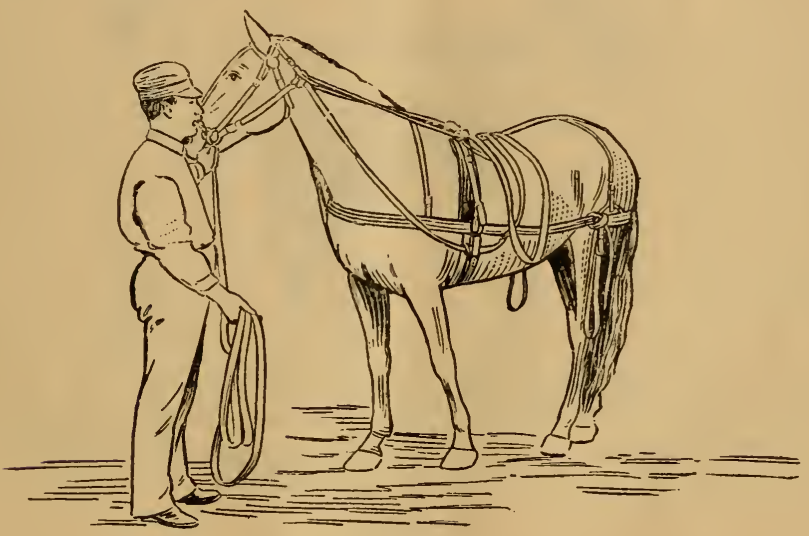

Fig. 8.

BRIDLE, REINS, THOYG FOR CHECKING, REINING-RINGS, AXD SAFETY REIN ADJUSTED FOR GIVIXG REIXIXG LESSONS.

loop, and when it is taut between the bit and loop, hold it and the loop together with the fingers of the left hand, and with the right hand make a knot in the leader below the loop. Fix the off leader in the off loop in the same manner and at exactly the same place. Put on the saddle and buckle the girths and crupper, add the breast-plate and tie the tugs into the breeching. Snap the reining-rings (a description of which you will see in fig. 2) into the buckles on the inner girth: Run your leaders through the reining-rings, buckle the hand-pieces on to. 
the leaders, buckle them together and let them lay across the colt's back. 'Take a leather thong as described in fig. 2, or piece of rope size of a clothes-line and fourteen feet long, tie one end in the near terret-ring, put the other end through the near loop, then under the water-hook, then through the off loop, then tie it to the off terret-ring, letting the colt have about four inches slack from a natural carriage of his head. Then suap the safety rein on to the near bit-ring, and every-

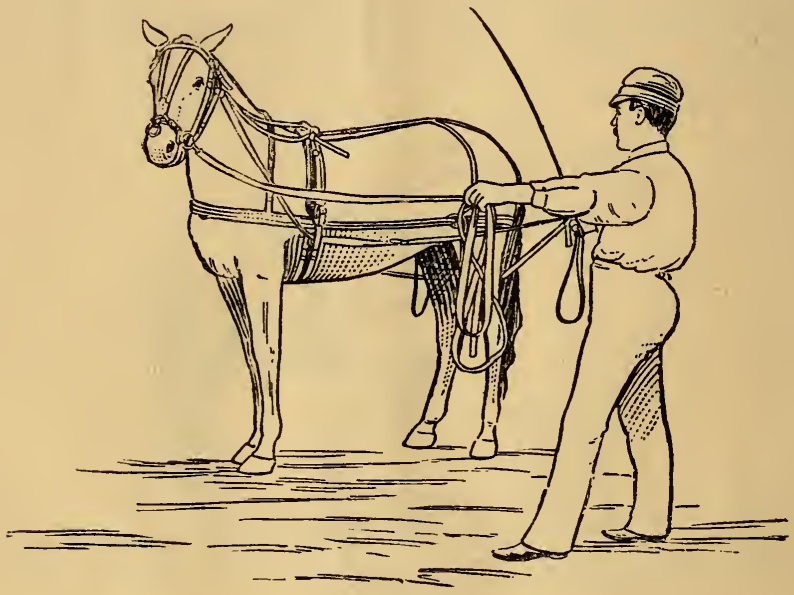

Fig. 10.

POSITION OF TRAINER IY BEgINNING TO REIN THE COLT, AND TO PROPEL A HURSE TO THE FRONT BY TOSSING THE SAFETY-REIN.

thing is in readiness for handling and educating your colt as is shown in fig. 9. Now gather the safety rein in the left hand and grasp it firmly a few feet from the bit. With the whip in the right hand also take hold of the reins with the right hand and toss them over his rump, letting them lay about his haunches as in fig. 10. If he resents this and tries to kick, drop the reins below his hocks and hold them snug to his heels. He will stop it. Then cluck to him and start him about you to the left. As he gets accustomed to the situation gradually 
work away from him on the safety-rein, at the same time pulling gently from time to time on the off rein until you see that he answers to it and will turn to the right when you touch on that rein. Gradually enlarge the circle and work back on the safety-rein until you are at the end of the reins and he goes about pleasantly. Then change the safety-rein to the off side, take it in your right hand, the whip and reins in your left, toss the reins about his haunches and work him in a circle to the right, pulling on the near rein until he answers to it, and working gradually away from him on the safety-rein until you are at the end of the reins again. Then let him walk about the floor, reining him from right to left, easy at first, then gradually harder as you see that he understands what is wanted of hin, until finally, you can grasp the reins firmly and begin to chang:e his direction suddenly from one side to another, and break him up thoroughly on the reins from right to left, pulling strongly across his hamches with the reins and teaching him to move his body with his head. Handle him in this way, letting him rest from time to time, until he will answer readily at a slight touch on either rein. Your colt is now a good reiner.

While handling him as above described, you should use the whip enough to give you motion to handle on. If he should get sulky and refuse to go, step to his side as in fig. 10, about eight feet away and toss the safety-rein forward so as to throw the bit to the roof of his mouth. This will start him. If he should come out, as is sometimes the case, duller on one rein than the other, work him about on the dull side until you get his moutl evened up.

The next thing to do, is to drive the colt about the stable and yard and hunt for places where he will refuse to go. As often as you find theni, step to his side about eight feet from him, as in fig. 10, and throw the safety-rein to the front, at the same time grasping the reins, which are about his haunches, with the other hand, as in fig. 10, and tapping him with the whip) until he goes where you want him to. Repeat this two or three times until you can step behind him and drive him to the spot 
without tossing the safety-rein. Drive him into every corner of the stable and to the wall, making him stand with his nose close to it. When you take him into the yard and road, drive him through soft places, puddles of water, brush, up to fences and fence-corners, up steep places and over boards and ditches. He will refuse to go to most of these places and you will have an opportunity to compel him.

The object in hunting for places to which he will refuse to go, is to get an opportunity to discipline him and get it into his head that he must go wherever you ask him to. Your object, also, is to educate him to answer to the tap of the whip and the word of command so that he will obey them every time; for, as I have said before, he will not be properly educated nor safe to drive until he will do so. Every horse should be educated to be whipped; yet there are some that you cannot whip in order to educate them to be whipped. Still you should have some means of getting them to go to the front when commanded, else you are liable to get into a bad predicament at some time. Here is where the benefits of the safety-rein come in ; for no horse can resist the forward toss of that rein, which thumps the bit to the roof of his mouth, and by tapping him with the whip when you toss the safety-rein to the front, although it is the rein which really compels him to go, by repeating it a few times he connects the toss of the rein with the tap of the whip and it soon becomes the whip that does it. In this way every colt or horse can be taught to answer to the whip. You cannot be too faithful in searching for places to which the colt will refuse to go, nor too patient and persistent in compelling him to go. If you cannot find any such place on your own premises, go out into the road or on your neighbor's premises and hunt until you do find them; for if you don't find them for him during his early training he will find them himself in the future, and your negligence will cause destruction to life, limb, or property. A colt that has never refused to obey is unsafe to drive, for no chance has been had to discipline him. Failure to take the above precaution has 
resulted in more destruction to life and property by unruly horses than any other cause. Want of discipline is inexcusable. Too severe discipline may be excused if the results are gratifying.

The safety-rein will give yon the adrantage over the colt or horse in many ways; but its great value is in the fact that it allows you to retain your control as you gradually work back to the end of the reins. Before you attached the safety-rein to the bit, all your handling had been mainly at the head and you had obtained perfect control there. If you were now to go to the end of the reins without the safety-rein to run back on, there would be fourteen feet orer which you had not handled and controlled, and it would take you a long time to regain your mastery there. But with the safety-rein to work back on, you retain your control as you go, and remain just as much master at the end of the reins as you were at the head; besides which, you keep the colt's attention upon yourself as you go, which is necessary in order to educate him easily:

Care should be taken to not handle or try to educate the colt when he is tired. Whenever he shows signs of weariness, put lim up and let him rest. You cannot make a proper impression on a wearied colt's mind.

Feed him well when handling and keep him in good strength and spirits. Avoid getting angry. Be patient, firm and persistent in all you undertake with him.

\section{LESSON XI.}

TO EDUCATE THE COLT TO BACK BY THE REINS.

Have bridle on for full control and reins arranged as in fig. 9 , with knots in leaders below the loops and the leaders through the "reining-rings"; also have on "safety-rein." Take position behind the colt and grasp reins firmly in both 
hands. Begin to pull back steadily on the reins, gradually increasing the pull until he steps back; and the moment he does, slack away on the reins and show him he has done right. Then pull back again slowly, and repeat until he readily backs when you pull. Then pull and say "back," and repeat until he knows what "back" means. It will now be necessary to contrive some place where he will refuse to back, and when he does, grasp the "safety-rein" in the left hand and shake backward on it, at the same time pulling steadily back on the reins with the right hand. The tugs should be tied into the breeching so he will be backing against a tight breeching, and he should be reined about on the floor and in the yard while backing, so as to teach him to be reined in backing.

Some colts will sulk and fight while being taught to back on the rein, but you must keep cool. If he braces and refuses to back, just brace yourself and keep one steady pull. He will soon yield and step back. If he should begin to sway and attempt to throw himself, slack away on the reins, and when he stops, pull steadily back again. If he should succeed in throwing himself, turn his nose into the air and turn a teacupfull of water down one nostril. This will bring any horse to his feet if he is alive. Do not try to force him to back too soon. Work easy at first until he thoroughly understands what you want, then force him gradually. Teach him to stop backing at the word "whoa." He should be taught that "whoa" means to stop and stand still, no matter what he may be doing. When he first backs, he simply does it because he wants to. There is a difference between the horse that does a thing because he wants to and one that does it because you want him to ; and, in order to get him to do it because you want him to, you must get him to refuse and then force him beyond his refusal. He is then disciplined, and not before, 


\section{LESSON XII.}

TO EDUCATE THE COLT TO STAND AT THE WORD "WHOA" FROM BEHIND.

This can be done while you are giving him his reining lessons. Have bridle and reins as in fig. 9. When driving him about the floor and yard occasionally say "whoa," at the same time setting back on the reins sufficiently to stop him, and repeat this until he will stop at the word on a slack rein.

Speak only the word "whoa," unless he is a trotter, when you should educate him to stop at some other word, or some one might "whoa" him on the track and you would "get left." After saying "whoa" don't speak to him if he mores, but correct him with a slight tug on the rein, and teach him to mind the one command. Never jerk on a slack rein to correct the horse under any consideration, but tighten the rein and give a pull on it; it is far more effective as a correction and will not get him afraid of his mouth.

\section{LESSON XIII.}

TO EDUCATE THE COLT TO THE SHAFTS AND TO PROPERLY SHAFT HIM.

Have bridle on for full control. Holding both leaders in left hand at corner of jaw as in fig. 5, bring lim up to the shafts with his head towards the vehicle. Reach under left arm and pick shafts up with right hand. Hold them up to his head until he examines them. Then rub his neck and head with them, and, as he gradually gets used to them, touch him in with the left hand, rub the shafts all about his body and legs and let them drop on the floor and rattle about him. Then back him ont, stand lim square to the ends of the shafts, 
hold him in control with the left, while with the right you raise the shafts up and run them straclle of his fore legs, then in between his fore and hind legs, rub and thump his belly with them, then run them straddle of his hind legs and rub them against his heels and gambrels. Then place them on his back, square across him, and rub and thump him with them until he shows no objection. If he objects give him the "controlling touch" with the left hand. Finally, with the left arm of the shaft in the right hand and the right arm laying on his croup,

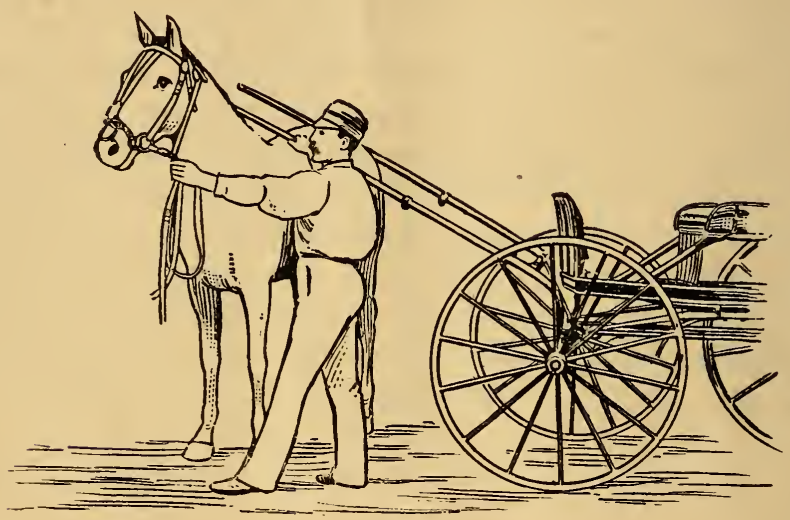

Fig. 11.

POSITION FOR SHAFTING THE COLT OR HORSE AS IN LESSON XIII.

as in fig. 11, touch him under the chin with the left hand; he will whirl under the shafts and they will drop down to his side. You now have the colt in the shafts, you have hold of him with one hand and the shafts with the other. You can then play them all about him and rub the cross-bar against his haunches until he is indifferent to them. If he objects, give him the " controlling touch."

Another pretty method of shafting a colt, or horse of low stature, is to bring him up to the near arm of the shaft and square to it, with the left hand. Cross the right arm over the left, pick up the near arm of the shaft in the right hand, raise 
it up alove the colt's head and lead him under with the left hand, whirling on your heels as he comes under and turning him to the left. When he gets under, drop the shafts about him and then play them all about his body and legs. In a dozen lessons any colt can be taught to go under the shafts in this way, and he will bring ten dollars more.

Inasmuch as the shafts and vehicle are going to be his companions through life, it is but fair that he should be giren a proper introduction to and have a fair acquaintance with them. No colt or horse is properly educated until he will stand the cross-bar against his heels or the shaft between his legs without fear ; and with the perfect control that my bridle gives, it is as easy to educate him to the cross-bar as it is to the breeching. The perfect education of the colt in this respect is necessary for the safety of your wives and children. Many loved ones have been killed or maimed and much valuable property destroyed, which is the direct result of carelessness and indifference on the part of those who call themselves "colt trainers."

Make it a rule throughout the education of the colt, to reward him with a caress and word of approval every time he obeys you. IIe will soon learn to know when you say "thank you" to him by caressing him; and, after you hare repeated it a few times you will notice him ducking his head to you and saying "you're welcome" just as plain as he can talk, - and hor'ses do have a way of talking to man.

When educating the colt, it should be a rule to give him a rehearsal of his first lesson before you proceed with his second, and rehearse the first two before you give him the third, and so on to the end of his lessons. Then when you are all through, give him two or three rehearsals of them all so as to fix them on his mind; and these rehearsals should be repeated, until he goes throngh each performance in a pleasant manner and without shaking his head or showing evidence of unwillingness : for just so long as he exhibits a sign of wilfulness he is not safe to drive. You may be able to drive him, but you cannot 
afford to jeopardize him or yourself ; for one colt, not fully disciplined, can do more damage than would pay for the perfect education of a dozen. Yon may he in a hurry to get him out on the road, and you may think that, to follow these rules entails a great deal of trouble and takes a great deal of time; but consider that, when you do start out with him, you have an educated colt and one that will be a credit to you and your skill, and the result will satisfy you. Neither does it actually take so much time to educate him by following these rules as it would to harness him in, start him on the road and let him pick up his education; for, by this method it will take less than a dozen lessons of one and a half hour each to educate him perfectly, while the old process will require months of driving, and you incur the risk of your colt's getting the better of you and acquiring some bad habit. Remember that it is the education of the colt that brings the money, and you will spare the necessary time.

\section{LESSON XIV.}

\section{DRIVING THE COLT TO A VEHICLE.}

Have the harness on properly, be sure there are no weak places in it and see that it fits well to him. Have the keeper about two inches above full control. Buckle the loops halfway down to the ends of the over-draws. Have the throatlatch reasonably loose. Snap the reining-rings in the buckles above the thill-lugs. Run the leaders through the loops, then through the reining-rings and buckle on the hand-pieces. Snap the safety-rein on the near bit-ring, adjust reins and bridle as in fig. 12, and add the thong for a check. Drive the colt about the yard and road for ten or fifteen minutes, then lay the reins across his back and shaft him as in Lesson XIII. While hitching tugs and hold-backs, have safety-rein in one hand. Fasten the tugs first then the hold-backs. When 
all is ready, take safety rein in left hand a few feet from the bit, and whip and reins in right hand with the off rein about his haunches as in fig. 10. Start him up a rod then stop and let him examine things. Start him farther and stop again. Then start him in a circle to the left, and as you see that he understands it, gradually work away from him on the safetyrein and enlarge the circle by pulling on the off rein about his haunches. When you have worked back to the end of the reins and he goes well, change the safety rein to the off side

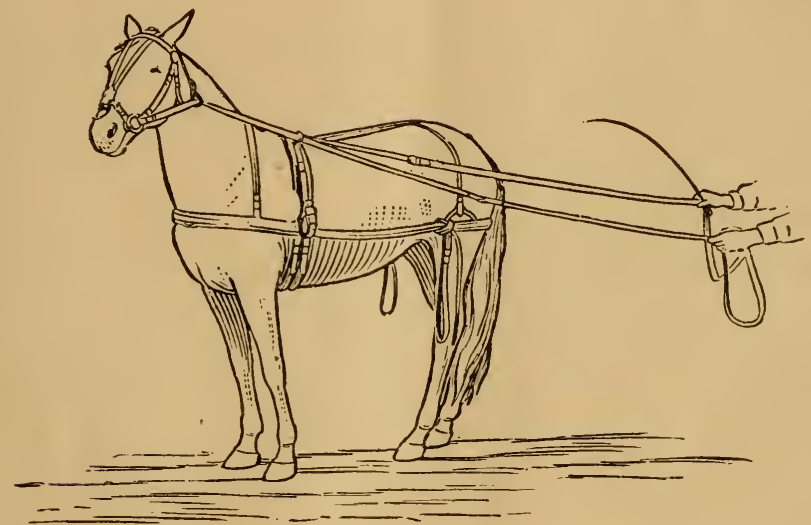

Fig. 12.

ARRANGEMENT OF REINS AND OIERDRAWS FOR MRIVIYG INTIL THOROUGHLY EUUCATED.

and work him in a circle to the right until you have worked back to the end of the reins. Then drive him ahout in a figure 8 , changing from one side to the other as you do so. You can soon step up on the vehicle and ride a ways, first on one side then the other. Then you can soon drive about the yard and finally on to the road. When on the road, carry the safetyrein on near side in left hand, and when you meet a team, if he stops to "neighbor" with other horses, as most colts will, toss the safety-rein to the front; and if he acts afraic of the team, lean over to the left and hold him up to it with the 
safety-rein. After passing a few teams he will not notice them. Give the colt short drives until lie gets hardened to the road. Drive out on different roads each time, and don't turn nim about in the same place when repeating your drives on the same road. If you turn into a yard one day, drive past that rard the next time you go that way. Don't let the colt get in a habit of wandering along in the road between the ruts. lieep a firm rein always, on colt or horse, and occasionally rein the colt out from one side of the road to the other; and when you can, drive him outside of the road along the fences, turn him around in the road and back him in different direc1ions and places. In fact, teach him to go everywhere you rein him; and when you drive in the track made by other horses, have him go there because you want him to, not from force of habit.

Don't watch the wheels to see if they are in the ruts. Keep your eyes about thirty feet ahead of your horse, see that he goes in the proper place and the vehicle will follow. In driring colts or timid horses, it is your duty to keep watch ahead for dogs, children, stumps, $\operatorname{logs}$, piles of wood, brush or lumber, rocks, cattle or horses in the road or fields, etc., etc., and see them before the colt does; and if he pricks his ears or gives evidence of shying, be ready for him. The proper thing to do on such occasions, is to move the bit in his mouth by trigging slightly on first one rein then the other, thus taking his attention to his mouth and reminding him of the control, speak to him, and if he hesitates to go to the front tap him with the whip; if that doesn't do, toss the safety-rein to the front. Teach the colt to slow up in rough and trot along in smooth places. Don't be in a hurry to make a trotter of him. Don't drive too long nor too fast at a time. Don't work your colt on the road after he gets weary. Feed well when training. Don't check high; give him at least four inches below the natural carriage of the head. Use the leather thong or rope as a check, until he is well educated. Handle him about the stable and yard for ten or fifteen minutes before hitching him up the 
first five times. It serves to get him under control. Teach him to stand still after hitching up, until you tell him to go.

It is not advisable to let up too much nor too suddenly witle your control. Until the colt gets " waywise," it will stand yoi in hand to keep him under perfect control ; for the least inattention on your part may result in trouble. If you don't want the colt to do wrong, never let him know he can, and when his education is complete he will not want to. As you see that ha gradually learns, let up on your control by moving the keeper up and dropping the loops down. When ha is finally wel:behaved on the road, take off the reining-rings and loops, put on the over-draw extension, and drive with the reins running from the bit-ring direct through the terrets. If when driving ia this manner, you wish for control in any emergency, pull the keeper down and run both reins through the split in the over-draw. If you want to make an ordinary snaffle-bit out of a Wilson, four-ring bit, buckle both rings into the reins. Carry the safety-rein as long as you deem it necessary.

When introducing the colt to a locomotive for the first time, circle about and gradually approach nearer and nearer, until you can drive him alongside. 'The safety-rein should be carried on the near side if you circle to the right, and the off side if you circle to the left. If, when you approach nearer, $h 3$ is inclined to shy away, swing out and hold him up on the safetyrein. Don't drive him too close. Twenty or thirty feet away is near enough for all practical purposes. When he will stand head or side to the train, then teach him to stand stern to it. The greatest care should be used in handling colts to objects of which they are afraid, and not give them too large a close at a time, for it rattles or confuses them, and the impression is not permanent. A good rule to observe all through his education is to "go slow."

\section{OPEN BRIDLES.}

Every colt should be educated in an open bridle, and if you have perfect control, which the use of a bridle like mine will 
give, it is no more difficult to handle him than it would be in a blind bridle. An open bridle will give the colt an opportunity to see the vehicle and other objects and get acquainted with them, and he will not be afraid of them in the future; whereas, if he is educated in a blind bridle, the first view he gets of the vehicle will be over the blinders, and that being an indistinct riew, and he being unable to sec his driver and be assured by his presence that all is right, he will become frightened and liable to break away from control.

It would be better for the horses if they all could be driven in open bridles: and every thorough horseman can drive successfully with open bridles, while poor horsemen and indifferent drivers need to drive with blind hridles. A good horsemain will have his horse educated and under control of the word of command, will keep his horse well in hand everywhere and be ready for every emergency. 'To such a man it matters not if his horse has on a blind or open bridle. An indifferent driver, who sits with his elbows on his knees and the reins dangling loosely about his horse, should use a blind bridle ; for with an open bridle the horse will watch him, take advantage of his negligence and soon become a lazy beast.

\section{CARE OF THE TEETH.}

Colt trainers should make it a rule to examine the teeth and mouth of every colt before beginning to educate them. This can be easily done by carefully taking the tongue out to one side with one hand, and with the fingers of the other hand feeling on the inside of the lower grinders and the outside of the upper ones, to see if there are any sharp teeth cutting either the tongue or cheeks. If any are found they should be filed. If no veteriuarian is at hand, grind off the corners of a file, fill up one side with bees-wax and dress the tooth yourself. Examination should also be made to see if the surface of the griuders are even and no tooth projecting beyond the others. If any such are found they should be either cut off with proper 
instruments or extracted. Sometimes, also, ulcers or cankers can be found, and these require treatment by a veterinarian. A great deal of trouble in handling colts can be avoided by these precantions, for faults attributed to viciousness are often the result of sore mouths, and the cause being removed the fault disappears.

Men who are constantly buying or changing horses should examine the mouth of every new horse, and if the teeth are in bad order attend to them. Many of the most aggravating faults can be traced directly to a bad condition of the teeth. Bolting, pulling, lolling, fighting check, and side-reining can be attributed in the majority of cases to the teeth. The fact that no irregularity, sharpness of the teeth or sores on the tongue or insicle of the cheek can be seen is no proof that the teeth are all right. 'There may be ulcerated teeth, decayed teeth, or split teeth, with all the consequent achings to which people are subject from the same causes. Authorities in veterinary science cite numerous instances where an offensive discharge from the nostrils led to the belief that it was a case of glanders, when an examination proved it to issue from an ulcer or abscess at the roots of the teeth, which har discharged into the nasal cavity. It is very apparent then, that a frequent and thorough examination of colts' and horses' teeth will be productive of good results.

\section{LEADING HORSES BY THE REIN.}

It should be a rule when leading horses about by the bridle, to change sides and lead as often by one rein as by the other. The constant leading of horses by the near rein only, and the coustant pulling back on that rein in order to hold the ambitious horse, serves to educate but one side of the mouth, and the result is that the horse soon becomes a side-reiner on the opposite rein. The fact that the majority of side-reiners pull on the off rein proves this. This can be remedied by changing about and leading as often on one side as the other. 
CONCAVE ROOF IN THE HORSE'S MOUTH.

It will be noticed in handling some horses and colts, that, when you give them the "controlling touch," as explained in Lesson III, they will not appear sensitive to it. An examination of the roof of the mouth, in such cases, will show it to be very concave; consequently the center of tha bit does not reach the center of the roof and no control is obtained. In such cases the centre of the bit should be wound with copper wire, or raised by fitting on a wooden button, high enough to reach the centre of the roof of the mouth.

JERKING ON THE REINS.

Jerking on a slack rein to reprove a horse soon gets him so afraid of the bit that, whenever he sees a hand approach his head or feels a tremor of the rein from behind, he will throw his head in the air, expecting the accustomed jerk. If it is necessary to reprove on the rein, it will be more effective to take hold of the rein firmly, pull it taut, then set on it with a firm pull; and this will not get the horse afraid of his mouth. Never jerk, or "fish," on the reins when you wish a horse to go or increase his speed. Ordinary road or family horses should be educated to go slower as the reins are gradually tightened; but for gentlemen's road horses, or trotters, the opposite rule should be observed, to some extent, for it is essential that a trotter should bear well on the bit in order to steady himself.

\section{APPROACHING AN UNRULY HORSE.}

In approaching a horse, especially if he be inclined to be ugly, let your manner be firm, and speak the word "whoa" in a quiet but firm tone. Grasp the rein near the bit, say " back," "get up," "get over" or " come here," at the same time touching firmly on the rein in the direction corresponding 
to the command. This will have a decided effect on hin and he will conclude you are not to be trifled with. If he is very vicious, fasten a large grain-sack to a hoop, fasten the horp to a pole and bag his head. Being blinded he will stand still. Fasten a slip-noose about his neck forwarl of the hoop. Cut holes through the sack to let his ears out and a hole to get the bit into his mouth. Put on the bridle and handle him for awhile with the sack on his head. When placing your hand on any part of the horse, do so in a firm, decided manner. Never indulge in any foolishness about a horse. Never tease him under any circumstances and never allow any one else to do it. Never indulge in any undue familiarity with a lorse. It breeds contempt. Discharge a quick-tempered, blowing, blatant groom whose very presence is odious to the horses. Let your motions about the horse be easy, silent as poss.ble, and quick, without being jerky. These rules, intelligently followed, will cause your horses to love and respect you.

\section{MESMERIZING HORSES.}

Many ignorant people suppose that some men possess certain powers, generally termed mesmeric, orer hor'ses and other animals. This is so just so far as these men possess firmuess, patience, skill and tact, coupled with a faculty to foresee the animal's intention and a readiness to prevent him from carrying it out; and, combined with all this, a method of letting the animal know, by rewarding him for obedience, that they are friend as well as master. No man need possess any greater magical powers than to have thcse qualities. They, together with a means of control in whic'n there is no torture, will give him control over, and enable him to effectually mesmerize any horse.

THE COLT'S TAIL.

If a colt carries a good tail his value is increased considerably. Throwing the tail well up over the back will help some, 
as it tends to loosen the muscles on the under side of the tail, thus letting it rise. If the tail is light, the crupper should be enlarged, by winding it with felt, flannel or leather, so as to hold the tail up; and this should be worn until the upper muscles get strengthened and will hold the tail up. If the tail is heary, it should be combed out, and then it should be thinned out carefully and evenly by slashing dowuward with a sharp knife until it is relieved of its extra weight. This will cause the tail to spring up, and by the time the hair is grown out the muscles will have become set and will give it a permanently good carriage. The horse that will hold the rein down when he gets it under his tail, should wear a crupper large enough to hold his tail away from his rump; then he cannot hold the rein when he gets it under his tail.

\section{RULE FOR HITCHING AND UNHITCHING.}

After placing the colt or horse in the shafts, always hook the tugs first, then the hold-backs. When unhitching, unhook the hold-backs first, then the tugs. If this rule is followed, the value of a good many horses will be saved. Horses that acquire the habit of bolting out of the shafts when being unhitched, do so by having the tugs unhitched first and getting caught by the hold-backs when going out.

\section{BITS.}

No general rule can be given for the use of bits. In educating a colt or unruly horse we must use a form of bit which will give perfect control until his education is finished; and the four-ring, double-joint Wilson bit, used with a bridle constructed as in fig. 2 and according to the instructions in this book, will answer all requirements. For general driving, a medium sized snaffle is best; but horses differ so greatly in disposition and sensitiveness of the mouth; that a close study of the animal is necessary in order to determine what bit to use. 
LOW CEILINGS IN STABLES AND STALLS.

The habits of halter-pulling and being unruly in bridling are of ten caused by horses striking the tops of their heads against low ceilings or timbers in the stables. Besides being the cause of these faults, low ceilings admit of poor ventilation.

TO BRIDLE A HORSE PROPERLY.

'Take the bridle in right hand with the thumb under center' of crown-piece. Lay the bit in left hand between the first and second finger's and forward of the thumb. Bring the bridle before his face and the bit to his mouth. Touch him under the upper lip, back of front teeth, with left thumb (every horse will open his mouth if touched there), and cause the bit to enter his mouth by raising the bridle with right hand. Then gather the fore-top in left hand, tuck the off ear under the crown-piece with right thumb, then the near ear and pull foretop out with left hand. The bridle is on properly and the fore-top in proper shape.

\section{TO GET A HORSE UP.}

If a colt or horse should get down and seem unwilling to rise, turu his nose up and pour a cup of water down one nostril. If he has life enough in him to enable him to get up he will come to his feet instantly.

TO EDUCATE A COLT OR HORSE TO STAND ON THE STREET.

Carry a lad about fourteen years old with you in the vehicle. Also hare a supply of potatoes or apples. When you have said "whon" and stopped the horse at the place you wish to call, give the lad the reins, have him crouch behind the dash or stand behind the rehicle, and instruct him to give a quiet 
pull on the reins when the horse moves, and to immediately slack up when he stops. The horse will look about, and, seeing no one will start again, when the lad will repeat the pull on the reins. This must be repeated by the lad without his saying a word to let the horse know he is there. When you return to the vehicle, give the horse an apple to eat and caress him each time. In two days time, if you have many calls to make, your horse will be afraid to stir after you leave, and will learn to wait for the apple he will get on your return. This is the simplest and most effectual method ever practiced, and will not fail. 


\section{The Education of Unruly Horses.}

Since Rarey entered the field and amazed people by his, then, wonderful and fearless exhibitions in taming unruly horses by subduing and exhausting them, numerous other men have travelled over his ground and become more or less renowned, according to their ability to handle. Each of them have taken Rarey's method of subduing as a pattern, and none of them have improved on his method, except by adding another hitch, knot or tie to the brutal cord, and using rarious forms of footropes or fetters, which would enable them to punish more severely and subdue more quickly. All of them subdued their subjects before they attempted to handle them. Each of them depended on exhansting the horse, breaking his will and inspiring him with fear, and their success depended entirely on their ability to "cook" the horse, as is frequently said of their methods. But as $I$ have said before, as long as that was the best method then known, it was far ahead of no method, and men felt justified in adopting it although it went against the better feelings of many to do so. Not one of them ever controlled the horse in the true sense of the word, but punished or frightened him into obedience.

Subduing, means to bring under power, to overcome by force, to crush or oppress, to coerce into submission. We see, by the definition of the word, just what their methods accomplished. To break his will and overcome the physical power of 
the horse was then their object. The will power and physical endurance of the horse, as in man, are his most valuable qualities, and when these are broken down and eliminated there is nothing left. The retention of these noble qualities in the horse is what has enabled him to gain the position he to-day has in popular favor, and it should be the trainer's study to control and educate the animal without subduing.

Controlling, means to restrain, to govern, to direct, to manage. That is, it implies the use of superior skill, tact and knowledge. It means to use such restraint as will keep the horse from doing wrong, at the same time to direct him as to what is right by a reasonable method of explanation. In the same way that a thoughtful parent controls his child by appealing to his pride and manliness, so should the trainer control his horse by appealing to his intelligence and letting him understand for himself that obedience brings reward, while disobedience brings none. The horse should not be taught to fear his trainer, neither should he be taught to obey through fear of punishment. There is no reforming power in punishment or fear. You may be able to scare a horse so he won't do a wrong thing, but you can't scare him so he won't want to. 'The aim, then, should be to restrain him from doing wrong, and explain to him what is right by removing whatever restraint you may use the moment he obeys. He can understand this treatment and will soon learn what is wrong by having the control applied when he is in the act of doing wrong; and he will learn what is right by having the control removed when he obeys. It is nonsense to think the horse knows intuitively right from wrong. The only way in which you can explain to him what is right, is to allow him to do it when he attempts to. And the only way you can explain to him what is wrong, is to apply restraint when he attempts to do wrong and repeat this often enough to educate him.

Education, as applied to the horse, consists in repeating the act as often as is necessary to make a permanent impression on him. He should be made to go through each lesson until 
he does it pleasantly and without the slightest sign of opposition. Then ke may be said to be educated. Men who profess to be horsemen have often asked this question of me: "If you train a kicker or halker to-day will he kick to-morrow?" and in asking the question they at once show how ignorant they are of the principles that apply to the education of the horse. Did they learn the multiplication table by repeating it once?' Did they become expert chopper's by falling one tree? I have always answered such questions candidly by telling them that, in all probability, the horse would kick or balk to-morrow. But I do say, that when the horse has had his lesson repeated so often that he has learned it as a scholar has learned his. tables, he will do right in preference to wrong.

Horses do many things we call unruly; and they really think they are doing right, because they have not been restrained from so doing and made to do the right thing. I can better illustrate my meaning by citing a case at Springvale, Me., which I had to handle. A young mare was brought. into the class which would rear whenever they attempted to. back her. She had never backed a step. Now, when the trainer first attempted to back her she happened to rear, and because he couldn't restrain her from rearing, she really learned that it was just what she should do when she heard the word "back" spoken and felt a pull on the reins. That. mare didn't know she was doing wrong and she didn't know what the word "back" meant, because she had never been put through the motion of backing. I simply held down on the near rein when she tried to rear and restrained her from it; then I taught her to back as I would a colt, and it took less than fifteen minutes to do it. The following day the owner could back her anywhere. She had learned for the first. time, the right meaning of the word "back."

In treating on the education of unruly horses we will take the road faults first. They are called by many names, such as bolting, pulling, shying, running away, balking, kicking, side-reining, rearing, running back, and afraid of locomotives, 
umbrellas or other objects; but, aside from the habits of rearing and kicking, all the rest of these fanlts simply amount to an excess of motion or porrer, in either one of four directions. To make this statement clear, let us stand a horse with his head towards the north. Now if he be a runaway or puller, he certainly has too much power towards the north or to the front. If he bolts to the right, shys at objects on the near side, or is a side-reiner on the near rein, he has too much motion or power to the right or to the east. If he bolts to the left, shys at objects on the off side, or is a side-reiner on the off rein, he has too much motion to the west. If he has the habit of running back, he has too much motion to the south.

In order to control these faults, we must get this extra motion or power, in whatever direction it may be, under control ; and educate it by diverting it in the proper direction. The proper way to do this is to take the horse on the stable floor, and, by following the directions given in these pages, work against this extra motion until you have brought it back under control. It is a safe proposition, that, if a horse is under perfect control of the bit and reins, he won't do wrong. The object is to make the horse think that we can manage him. When he thinks we can, that's all there is to it. The only reason that a man can govern an elephant is because the elephant thinks he can. If a horse thinks a bit can hold him, he won't pull or run away. If he thinks he must go where he is reined, lie will not bolt or shy. If he thinks he must go to the front whenever he is told to do so, he will not balk, or refuse to go to objects which appear frightful to him. To sum up, man's control over the horse should be superior to the horse's fear and every idea or notion of his own that he may have. Man was created lord over beasts. The Creator designed the horse for man's service. In His wisdom he certainly provided a means of control. We have a hint as to the means in the words: "there is the bridle for the horse." Horsemen who practice this system, will conclucle that the horse can be controlled and educated with the use of the bridle alone. 


\section{A RULE TO BE OBSERVED WITH EVERY HORSE.}

A general rule to be observed in educating any horse, no matter what his fault may be, is to first get your control at the head. If you cannot control and handle the head, clon't pride yourself that you can manage his heels. Get your control at the head by means of the "controlling touch," as in Lesson III. Bridle-handle the horse in every respect as you would the colt. See to it that his head is perfectly educated, and under control in every direction. Then gradually work away from the head, controlling and educating as you go, until you reach the point where the fault exists. Then control and educate there, until you satisfy yourself that you have eradicated the fault. In this manner, you make your control progressive. By putting the horse's nose against the wall, into the corner, and making him hold it there; then by handling him by the head and ears; then by handling him head and foot together, and putting him through sereral little motions, to all of which he will object, you add to your control a little at a time, until he finally acknowledges you as master in all things. Then, too, while gaining control you are educating the horse ; for each little act he has performed is something he will be required to do in the future. By getting control in this quiet manner, you keep the horse's mind calm, and in a condition to receive impressions; and the result is that he respects you as his superior, you have gained his confidence and he loves you as his friend.

\section{THE RUNAWAY HORSE.}

This is a horse with too much motion to the frout. Adjust the bridle for full control, and take position as in fig. 3. Lead him all about the stable and yard, occasionally giving him the "controlling touch," as described in Lesson III. , Stop him very often at the word "whoa," and compel him to stand still by touching straight down on both reins. If he is afraid of 
paper, robes, umbrellas, etc., hold him in control with both reins in left hand, as in fig. 5 , and play these articles all about his head and body until he shows no fear of them, giving him the "controlling touch" to make him stand still. Then work away from him on the leaders, letting him go about in a circle, stopping him occasionally at the word " whoa," by setting back on both leaders. Now put on saddle, and snap "reiningrings" on buckles on the inner girth. Buckle the loops on orerdraws, so the loops will be about seven inches back of crownpiece. Put leaders through the loops, tie a knot in the leaders, on the loops, run the leaders through the "reining rings," check with the leather thong, buckle on the hand pieces, and snap the safety-rein on bit-ring, as in fig. 9. Then, taking position as in fig. 10, proceed as in Lesson X., in getting a colt. under control of the reins. Repeat the word "whoa," at the same time setting back heavily on the reins, until he will stop and stand still at the word, without a touch of the reins. The horse is then under control of the bit, or he wouldn't stop at. the word; for it was the bit that made him stop in the first. place: and a horse under control of the bit, won't run away. Now fasten the keeper on the nose about an inch above full control, take the knot out of the leaders, run the leaders through the loops, then through the terrets, buckle on the hand-pieces, as in fig. 12 , hitch into the vehicle and drive out. When on the road, stop him occasionally by saying "whoa," and setting back on the reins. Also rein him from right to left; and, if he is afraid of objects, drive him up to them, using the safetyrein to make him approach them by throwing it to the front, as described in Lesson XIV. If he is afraid of the rattle of the shafts or wagon, handle him as in Lesson XIII. If he should attempt to run, reach out and cut him around with the safety-rein.

The first lesson will take about half an hour. Before you drive next time, give him another lesson of about fifteen minutes in the same manner ; removing control, as you think safe, by putting the keeper further up on the nose. Ten minutes is enough 
time for third lesson, before driving, decreasing the time each lesson until he is educated.

\section{THE PULLER.}

The runaway might be also called a strong puller, since his extra motion is in the same direction, viz., to the front. The puller is handled in much the same manner, before being driven, as the runaway. He needs to be taken on the floor, controlled, and educated on the bit by setting back on the reins until he thinks the bit can hold him. Before driving out with the puller, put the keeper up about three inches from full control and drive with the reins running through the loops and terrets as in fig. 12. If he drives on too slack a rein and doesn't take hold sufficient to make it pleasant, move the keeper up a little at a time until you get what pull you want. Care should be taken not to pull back suddenly if he starts to pull, but tighten the reins gradually. The first thing to do for a puller is to examine his teeth carefully and look all about his mouth for sores. If his teeth are cutting his tongue or cheeks, have them filed. If his mouth is sore, have it treated by a veterinarian. Removing the cause will remove the evil. If he pulls on account of a dull mouth he needs to have his mouth educated, and this is done by following the above directions. We can put different bits into runaways' or pullers' mouths, that will hold them; that is a preventive only. But this method of handling will educate them in a few lessons, so they will drive on any bit.

\section{THE BOLTER.}

Examine his teeth and mouth the first thing. Also look for the presence of wolf teeth. These are often a source of annoyance to colts and young horses, and their presence may be detected by feeling with the thumb on the upper jaw forward of and close to the molars. The fact that you can't feel them is not always proof that they are not there, for they may not be through the gum. If they are troubling the horse, and can 
not be seen or felt, a redness of the gums will disclose the fact. They should be removed at all events. This is sometimes done by breaking them off with a large nail and hammer, but it is better to extract them with forceps.

If the horse bolts because he is not under control of the bit, he should be handled and broke up on the reins, same as the runaway, until he is educated. Some horses bolt always to the right, some bolt to the left, and some bolt either way, as they take the notion. One that bolts to the right has too much power in that direction; or, in other words, he is not under control of the near rein. 'This one should be handled as the runaway is handled, with this exception: that especial attention should be paid to the near rein, and, after breaking him up a short time from right to left, as in lesson 10, he should be swung strongly about on the near rein; and this should be repeated until he gives evidence that he will answer to the near rein as readily as he will to the off one. You can determine when he is even on the reins by feeling of him carefully to see if he turns as quickly one way as another. The safety-rein should be handled on the dull side, and if he does not answer readily to the rein on that side, a strong pull on the safety-rein will bring him about. When he appears to be under control of the bit, from right to left, he should be driven into the corners of the stable, out into the yard and up to a number of objects to which he will object to go. When he refuses to go to any spot, step out to one side, as in fig. 10, and oblige him to go by throwing the safety-rein as described in Lesson 10, on handling the colt. If he bolts through fear of an umbrella, robe, etc., handle him up to the object by tossing the safety-rein to the front. When he appears to be under perfect control and ready to go anywhere you ask him, adjust reins same as in fig. 12 , hitch him to a rehicle and drive out. Carry the safety-rein on the near side; and, if he should attempt to bolt, lean out of the rehicle and cut him to the left with a strong pull on the safety-rein. Handle him a few minutes each time before driving him, until he is erlucated. 
If the horse bolts to the left he is not under control of the off rein; and you proceed just the same as with the one that bolts to the right, only you reverse by handling with the safety-rein on the right side until you get him under control of the off rein.

If he will bolt in either direction, with reins adjusted as in fig. 9, he must be handled sharply from right to left, same as the runaway, using the safety-rein on each side alternately, until he is under control of both reins and has concluded that he must turn either way he is reined. Then he should be handled up to the corners of the stable and up to umbrellas etc. in the yard, until he thinks he must go wherever you tell him, when the reins may be adjusted as in fig. 12, in driving a runaway, and the horse driven on the road.

Of course it is necessary for the trainer to keep a close watch of his horse and, if possible, learn by his actions what he is about to do and "get there" just before the horse does. The horse has generally been master on the road, and when he is started out, no matter how docile he may have acted while training him in the stable, he will have his sense of freedom and superiority return and may attempt to regain the mastery. To defeat this and hold him under control, as soon as you leave the stable you should begin to rein him from right to left, and keep his attention on the bit by trigging first on one rein, then on the other, and occasionally stopping him by saying "whoa" and setting back on the reins. When he pricks his ears at an object on the road, change the bit in his mouth sufficiently quick and sharp to hold his attention and remind him of the control. The lessons should be repeated with him each time before driving until he is under perfect control and obedience.

\section{THE SHYER.}

This horse should be handled exactly like the bolter that bolts either way, and driven with reins adjusted as in fig. 12 . If he shorld be shy of any particular objects he should, in 
addition, be driven to those objects under control, and compelled to stand still. By the use of this system on runaways, bolters and shyers, they can be bronght under such control of the bit and reins that they will not run, bolt or shy, no matter how much they may be frightened, for the control becomes superior to their fear.

Of course it is understood that horses of this character, and others with unruly habits, cannot be handled by this system or any other, so that they can be immediately driven by an indifferent or incompetent driver. It is necessary to hold such horses well in hand, be prepared for any emergency and to restrain them with coolness, firmness and judgment, when they attempt wrong, until they become thoroughly educated; and an educated horse will never go back on himself. Horses, like men, are peculiarly adapted, according to their organization and temperament, to different kinds of labor. Know well your horse and put him in the place he seems best calculated to fill. The mistake is too often made of trying to force the spirited, nervous, ambitious horse into a life of drudgery to which he is illy suited.

\section{THE SIDE-REINER.}

This is a name given to the habit a horse has of pulling harder on one rein than on the other. The habit, in some cases is caused by sharp teeth cutting the cheek, and the horse pulls on one rein to keep the cheek away from the sharp tooth. In other cases it is caused by a dullness or lack of education of one side of the mouth; and it may be the result of a paralysis of the nerves at the corner of the mouth, eaused by the use of the war-bridle or by brutally jerking the horse on the bit.

If it is caused by bad teeth, remove the cause by having the teeth filed. If it is caused by a dullness of the mouth, educate the dull side by putting the horse through a course of reining lessons on the dull side, as in handling the bolter, until he is 
as easily guided by that rein as by the other, using the safetyrein to assist you in educating him, and driving with reins adjusted as in fig. 12.

If the horse is dull on the near rein it can be attributed in most cases to his teeth; in the balance of the cases to lack of care and judgment in seeing that he was evenly handled on the reins when a colt. If he is a sidc-reiner on the off rein, it is generally caused by the habit of constantly leading him out to the vehicle, to water, and about the stable and yard by the near rein. The ambitious horse is being constantly jerked back on the near rein, and the result is that but one side of his mouth becomes educated. To avoid this result then, horses should be led out on each side, alternately, or by grasping both reins in the hand under the chin. In the balance of cases of side-reining on the off rein, the cause may either be bad teeth or injudicious handling. In order to determine how to educate a horse out of a habit, under this system, it is only necessary to ascertain in which direction the horse has an excess of motion, then intelligently proceed to bring the extra motion back under control and educate it by working directly against that motion.

\section{THE BALKER.}

Inasmuch as the balker will in most cases run back when he is urged to start, and as the same principle that will stop a horse from running back will start the balker, he may be said to be a horse that has too much motion to the rear; or rather, an absence of motion to the front.

Put on the bridle for full control. Handle at the head as in Lesson III, in order to obtain control, get up an acquaintance and show him you are master. Put on the saddle and adjust reins and safety-rein as in fig. 9. Then proceed as in Lesson $\mathrm{X}$, reining him about thoroughly on the floor, then stepping to the left side, with the safety-rein in the left hand, the whip and off rein about the rump in the right hand as in fig 10 , work him about the floor. Stop him frequently, and start him by throwing 
the safety-rein sharply forward. Repeat this until he will start forward on a slight toss of the safety-rein. Then, if possible, find some place to which he will refuse to go, and compel him to go by throwing the safety-rein, at the same time striking him smartly with the whip. If you can't get him to refuse to go anywhere, pile up some brush and oblige him to go through it repeatedly. Then hitch into a vehicle. Carry the safety-rein in the left hand, and when he attempts to balk, throw it strongly forward. If he should succeed in stopping, cut him about to the left on the safety-rein, and when he comes around throw the rein to the front, at the same time striking him smartly with the whip. He will prefer to go ahead rather than be cut around, and a few lessons will educate him. If a man has an unruly horse and he wants to educate him out of his vice, he should prepare himself so the horse can do no damage if he should have a contest with him on the road. It is better to harness an unruly horse to a strong sulky, or twowheeled gig, for the purpose of educating him. The trainer will not only have better control and be in a better position to handle by being close to his horse, but the horse can do no damage. If he is hitched to a wagon, it might happen that you would be unable to control him for fear of the result, and that wonld be a victory for the horse. Every precantion should be taken to ensure success; and a man is justified in adopting any measures he may see fit, that will give him the advantage, so long as they are not cruel to the horse.

The horse that has been loaded too hearily, and, becoming discouraged, has become a balker, needs to have his confidence in his powers restored by loading light at first, then gradually giving him hearier loads until he has what he ought to pull. The balker that will stand and allow himself to be tortured by fire without stirring from his tracks, is pronounced by reterinarians to be an insane horse. This is a reasonable conclusion, and the same thing might be said of other cases where destructive habits exist without any apparent cause. To those who have watched the strange freaks of those who are confined in 
a lunatic asylum, it would not be difficult for them to believe that many of the vicious habits of horses are the result of a diseased brain.

\section{THE POOR REINER.}

If a horse reins poorly, see if a bad condition of his teeth is the cause of it. If so, get his teeth fixed. If not, it is because his mouth is not educated. Adjust the bridle and reins as in fig. 9, and give him a few reining lessons as in Lesson $\mathrm{X}$, and drive a few times with reins adjusted as in fig. 12. Some horses are limber-necked and will swing their heads around without moving the body. Others are stiffnecked and will move neither head nor body. In both cases the fault can be orercome by a thorough course of reining lessons.

THE HORSE AFRAID OF THE LOCOMOTIVE, UMBRELLA, OR OTHER OBJECT.

Some horsemen profess to believe it a difficult feat to drive a timid horse to a locomotive, and doubt another's ability because they never were able to do it themselves.

This horse wants the bridle on for full control, as in fig. 3, and needs to be handled just the same as described for a bolter that bolts either way, only he needs to be handled with more force and decision. He should be reined about thoroughly, from right to left, on the floor, as in Lesson X., and handled to the front on the toss of the safety-rein, as in fig 10, at the same time the whip should be plied until he can be driven to the corner of the stable and to every part of the yard under the tap of the whip, without the use of the safety-rein. When ha will do this he may be hitched to a vehicle (a two-wheeled gig or sulky should be used, if possible), and driven out ou the road about twenty minutes or more before the train comes. (Before driving, remove the keeper one inch above full control and run the reins through the loops and terrets as in fig. 12.) This time shonld be spent in reining him about, turning him 
around and driving him to objects to which he will object to go. When the train comes, he should be driven in towards it, and if possible, alongside of and with the locomotive. The safety-rein should be carried on the side that is going to come next to the train, and if he tries to dodge away he may be swung to the train by leaning out of the vehicle and holding him up on the safety-rein. If he attempts to stop, throw the safetyrein sharply to the front. If he tries to rear or run back, cut him off and around with the safety-rein, then head him towards the train again and say "whoa." If when handling him on the floor and road before the train comes, you have taken pains to educate him to what the word "whoa" means, he will stand still. The drives should be repeated until he will go within a reasonable distance and stand quietly. When going to the train, have him under a sharp trot and keep his attention on the bit by trigging on the reins.

Although many horses cannot be driven to the locomotive, very few of them are really afraid of it. The majority of them have always refused to go, and understand that the driver cannot compel them to. The balance may be said to be afraicl. In either case, by the use of this system, the control becomes superior, not only to their fear, but to any notions of their own that they may possess. It is simply a system which enables the trainer to make the horse think that he must go wherever he is reined; and when the horse thinks he must obey, that settles it. Some horses can be led up to a locomotive and will stand quietly with some one hold of the rein, but it would be impossible to drive them up. Some people are pleased to attribute this fact to the "confidence," with which the horse is inspired in the one who leads him. If this were the case, the horse would follow his leader without his having hold of the rein, if another person were in the vehicle driving. Yet a horse will not do this. This proves conclusively that it is not a case of "confidence" at all, but a case of control and education. This horse had been disciplined in leading to such an extent, that he was under perfect control as far as leading 
was concerned, and thought that he must go wherever he was led; but he was not under control of the reins, and knew he need not go where he was driven unless he was willing.

\section{THE RESTLESS HORSE.}

With the bridle on for full control, take position as in fig. 3 . Move the horse all about the stable, repeating the word "whoa" and setting down on both reins. Then put on saddle and adjust reins as in fig. 9. Then, taking position as in fig. 10 , start him and rein him about from right to left, and drive about the stable and yard repeating the word "whon" and setting back on the reins until he will stop at the word on a slack rein. Let him stop several times this way, then "whoa" and set him solid for half a dozen times. Put him in the shafts, hitch tugs and hold-backs, toss reins over the dashboard, step into the vehicle, and if he attempts to move say "whoa." If he has learned his lesson he will stand. If not, take him out and spend a few minutes more to finish what you have partly done. After a few lessons he will stand perfectly.

This is a hard fault to handle by all other methods; but by this it is a simple matter of teaching him the true meaning of the word "whoa."

\section{THE REARER.}

This horse should be handled with the bridle on for full control, as in fig. 3. Handle at the head with the "controlling touch," as explained in Lesson III, sufficient to get him to recognize you as master, then put on the sadile, and adjust reins, etc., as in fig. 9. Then give him a thorough course of reining lessons, as in Lesson $\mathbf{X}$., and while doing so, provoke him to rear hy trigging back on the reins at the same time tapping him with the whip. When he rears, or just as he attempts to, step off to the left quickly, as in fig. 10, and cut him down by throwing outwarl and downward with the safetyrein in the left hand. In this way you control him from 
rearing. When he rears he forces the bit against the roof of his mouth, and a few lessons will educate him not to do it.

\section{THE HORSE THAT BREAKS IN TROTTING.}

Put on bridle, have cheek-straps buckled so the bit comes just to the corners of the mouth, fasten the keeper on nose about four inches above full control, and drop the loops down to the ends of the over-draws. Run the leaders through the loops, then through the terrets as in fig. 12. Hitch to a vehicle and drive out on the road. When on the road, adjust the loops so that when the horse's head is at its natural carriage, there will be an equal purchase on reins and over-draws. If, when driving, the over-draws appear slack, buckle the loops up. When they are rightly adjusted, drive easy until he gets accustomed to the bridle, then gradually increase his speed and in the course of an hour he will be going nicely. If he pulls too much, put the keeper down on his nose. If he doesn't take hold enough, put the keeper up on the nose. If his mouth is too sensitive for a four-ring bit, have two rings put on a straight bit, then buckle the over-draws into the rings and drive as directed.

\section{THE CHECK-FIGHTER.}

Put on bridle for full control as in fig. 3. Put one end of a small rope through the ring on the center of crown-piece, bring it down and pass it through one of the inner rings on the bit, then over the nose and through the other inner ring, and fasten it in a knot, on the nose, to the rope. Then take hold of the other end of the rope, catch it under the water hook and take hold of the near leader with the left hand. Pull forward on the rope, and when he begins to fight check correct him by snapping down on the near leader. When he stops fighting, tie the rope to the water hook and lead him about for a few minutes. Repeat the lesson a few times, and when you drive, have the reins through the loops as in fig. 12 . 


\section{THE BITER AND STRIKER.}

This is always a case of viciousuess, and should be handled with firmness, care and patience. It usually accompanies a naturally treacherous disposition, and it is a difficult matter to reform the natural proclivities. Whatever good effects are to be had, can be obtained by a thorough and systematic controlling by the use of the controlling bridle adjusted for full control as in fig. 3. He should be handled in every conceivable manner, and made to do everything your ingenuity can devise that he will object to do. His head should be thoroughly handled in every direction as in Lesson $V$. It should be held down to first one fore-foot, then the other, by passing the leader under his fetlock and drawing on it. Handle his hind feet on the safety-rein as in Lesson $V$. and fig. 7 . Then make him hold lis nose up in the air and around to each side. Fasten the leader in the thill-lug on one side, thus holding his head around, and make him waltz around each way. Lay him down a few times, as in Lesson VII., then give him a complete reining lesson as in Lesson $\mathbf{X}$. In fact, show him that you are his superior, and can compel him to do anything you wish; this will cause him to respect you, and in a few handlings he will cease his vicious practices.

\section{THE UNRLIX STALLION.}

Adjust the bridle for full control and take position as in fig. 3. Touch him about with the "controlling touch," as explained in Lesson III., for about two minutes before handling to mares, and "cover" with the off leader over the neck, restraining him with the "controlling touch" when necessary. He should be thoroughly and repeatedly handled by the bridle and brought under control of it, as in Lesson V., when no mares are about.

A mare can be handled to a stallion, without the use of the fetters, by giving her the "controlling touch" a few times, 
and, when being covered, holding hard downward and backward on the off leader over the neck, at the same time holding her nose up with the left hand grasping the near leader close to the bit.

\section{THE HORSE BAD ABOUT BRIDLING.}

If very difficult to bridle, have the cheek-straps adjusted so the bridle will be loose, then put in the bit and pull the keeper down so as to get close control. Grasp both reins in left hand close under the chin, and cause the bit to press against the controlling spot in the center of the roof of the mouth. Then adjust the crown-piece of the bridle over the ears, fix the bridle for full control and take position as in fig. 3. Now handle the head and ears in every conceivable shape, as in Lesson $V$. and repeat the lesson until you have the head thoroughly controlled and educated. If the horse objects to taking the bit, unbuckle the bridle from the bit on one side, then, holding a side of the bridle in each hand, step before him, raise the bridle carefully up and drop it over his ears. Then put the bit in lis mouth and adjust the bridle, when you will handle his head and mouth and pass another bit in and out repeatedly, giving him the "controlling touch" whenever he objects. Some cases can be cured by letting them take a few pieces of apple from the hand, then let them take the bit and apple together and adjust the bridle when they are eating the apple.

In every case that is handled, no matter what the fault may be, it should be a rule, in order to get the best results, to reward the horse for every act of obedience by giving him a bite of something like apples or potatoes. In this way you explain to him that he has obeyed your wishes.

\section{UNRULY IN SHAFTING OR UNSHAFTING.}

Have bridle on for full control and take position as in fig. 3 . Handle about the floor by the "controlling touch," as explained 
in Lesson III., for a few minutes, and if he is afraid of the shafts, handle them all about his body as in Lesson XIII., in educating colt to the shafts. 'Then handle him in and out of the shafts repeatedly, until he goes pleasantly. Give him the " controlling touch" if he attempts to jump or plunge in or out.

TO CONTROL FOR CLIPPING, CASTRATING, BATHING SORES, CLEANING SHEATH, MILKING OUT, CRUPPERING, HARNESSING, UNHARNESSING, ETC.

Have bridle on for full control, and take position as in fig. 3. Give the "controlling touch," as explained in Lesson III., taking him around a few times and stopping him at the word "whoa" by setting straight down on both reins. Then proceed to handle as you wish, and if he objects, give the "controlling touch."

\section{INSTRUCTIONS TO BLACKSMITHS FOR CONTROLLING} COLTS AND HORSES FOR SHOEING.

Many jerkers, leaners, and horses that are restless in the shop, can be controlled by putting the hand across the animal's nose, and with the thumb in his month, bringing a pressure to bear with the end of the thumb in the center of the roof of his mouth, just forward of the molar teeth. The pressure of the thumb on the controlling nerve will control the horse; but, in addition to the control, it will serve to take his attention if you let the thumb-nail bear against the membrane a little. Many horses can be controlled by bringing a pressure to bear with the thumb under the lower jaw, up against the tongue, just back of where the jaw-bones meet. Most leaners can be shod without trouble, by stepping to the other side, or between the hind legs, and picking their feet up the other way. A horse that leans on the smith should not have his feet held up too high, and when he leans over, instead of holding up against him, the foot should be lowered a little. This will give him nothing to lean on, and in a short time he will stop it. 
Some horses are difficult to shoe because they have spavins or sore joints; and when the smith lifts the foot, he cramps the joints and hurts the horse. Such horses should be shod with the foot as low down as possible. If it hurts a spavined leg to stand on it while the other foot is being shod, keep the foot up as short a time as possible. A horse that has stringhalt, or stiff joints, should not have his leg stretched out too far behind.

The majority of colts and unruly horses that are bad about shoeing, can be controlled by having the bridle on for full control, and, taking position as in fig. 3, giving them a few touches with the rein over the back of the neck, taking them around in a circle a couple of times, sayiug "whoa," and setting down on both reins. 'Then, while being shod, let some one stand by the head and occasionally give him the "coutrolling touch" by touching down on the rein over the neck.

If a desperate kicker comes in, put on the bridle for full control, and put safety rein on off side in place of off leader. (See illustration of opposite side of fig. 6.) Then take position as in fig. 3. Give the "controlling touch" over the neck a few times by touching down on the safety-rein. Then throw safety-rein about his heels, and hang hold of the end, as in fig. 6 . If he has an ounce of brains, he will not kick more than three times on the safety-rein. Then toss the safety-rein over the back, and pass it under the fetlock of near hind leg as in fig. 7. Then handle a few minutes, as in Lesson V. and handle the foot in a loop of the rein while shoeing.

A quiet and firm manner on the part of the smith will have a great influence over a colt or horse in the shop.

Of course it is useless to furnish instructions to any man who will abuse a method; and the originator of any system need not be beld responsible for the imperfect workings of that system, if it is not intelligently applied. It is to be hoped that a general introduction of this work will stimulate those who grow colts to so educate them, that, when they are brought into the shop, the blacksmith will not be required to both educate and 
shoe them for the small pittance he gets for shoeing. Many men have said to me that "the blacksmiths are the ones to learn how to educate a horse's feet." I have replied, that " looking at it from the stand-point of a man who has no regard for either his horse or his fellow-man, that is so ; but looking at it from the blacksmith's side, it isn't a "fair shake" to ask him to break his back educating your horse, when he earns his money dearly enough by shoeing for the small price he is compelled to." But no matter how many systems there were introduced, every man wouldn't educate his colts' or horses' feet to be shod. Such being the case, the smiths must do it, and the easiest method is the best. More smiths have lame backs from their struggles in holding unruly horses' feet than from any other cause; and if the introduction of this volume will make their work easier, it will have served its purpose well.

\section{TO CURE A SWITCHER WITHOUT CUTTING THE TAIL.}

Divide the hair on the tail in two parts, and braid each part down to a point. Tie a strong cord, or small rope, about four feet long, to the end of each braid. Put a collar and hames on the switcher. Put the tail directly up over the back, and run the cords through the lower rings of the hames. Then pull the tail down snug enough to the back to keep it from dropping over to either side, and tie the cords in the hame-rings. Buckle a circingle about the horse, orer the cords to keep them in place, and let the tail stay up ten or twelve hours. Then take it down, and the switching is usually stopped. If it should return, repeat the operation.

\section{THE HALTER-PULLER.}

Bend down a birch, or other stout sapling, or pull down a long tree-limb, tie the halter to the top and let go. When the horse pulls, he can only sit down on his haunches. Let him work until he stops pulling, and repeat if necessary. 
TO PREVENT A HORSE GETTING CAST IN THE STALL.

This is usually caused by the habit of rolling in the stall. In order to prevent it, fasten a ring to the top of the halter; fasten the tie-rope to this ring, run it over a couple of pulleys and fasten a weight to the other end. Have the rope just long enough, so that, when lying down, the horse's nose will not quite touch the floor. If he cannot get hiz head down he cannot roll. Another method is to tie him with ropes from both sides of the stall, so that when he lies down he cannot get his head down to roll.

\section{TO PREVENT HORSES FROM NIPPING AND TEARING BLANKETS.}

Saw a block of wood three and one-half inches long and one and one-half inches square. Bore a three-sixteenths inch hole lengthwise through the center. Round the ends like the small end of an egg and round the corners a little. Put a cord through the hole in the center of the block and tie a knot in the cord at each end of the block. If he nips when grooming, tie this block in his mouth in place of the bit, by tieing the ends of the cord to the sides of the halter. If he tears his blanket, after he eats tie the block in his mouth. With this in his mouth he cannot shut his teeth together; and if he goes to nip, the block punishes him in the roof of his mouth and he soon stops it.

A nipping stallion can be cured of the habit by prodding him a few times up under his lip, against his upper jaw, with the thumb-nail. If you strike at him with the hand it is only an invitation for him to come again and serves to strengthen the habit.

THE BREACHY HORSE, OR ONE HARD TO CATCH IN A PASTURE.

Unstrand two old pieces of inch rope, four feet long each. Lay the six strands alongside of each other and tie them all 
together in a knot at each end. The knots should be a little over four feet apart. You now have a "western hobble." To put it on the horse, place the center around one fore-leg above the ankle, bring both ends together and twist the strands around until there is enough left between the twisted strands and the knots to go around the other leg, when you fasten the ends about the other leg by tucking the knots in between the strands and pulling them together. Pawing in the stall can also be stopped by letting the horse wear the "western hobble," as described for breachy hor'ses.

\section{KICKING IN STALL AT NIGHT.}

This fault can be eradicated by fastening a strong suspender buckle to one end of a piece of stout elastic webbing and buckling it tiglitly about the leg just above the hock. The uneasy sensation produced by kicking will cause the horse to stop the habit.

CROWDING AND KICKING WHEN ENTERING THE STALL.

Control and handle as with the biter, then, with the safetyrein on near side and through the loop on near side, pass in and out of the stall, correcting on safety-rein if he attempts to kick or crowd. Repeat the lesson until a cure is effected.

\section{THE KICKER.}

The first thing to ascertain, if possible, is, why does he kick? There will be found to be most as many causes as kickers. If the horse kicks from sheer ugliness, or desire to destroy, he should he taken in hand and controlled and educated all over and all through, until a thorough reformation is made. With such a horse, begin by controlling and educating the head by handling him as in Lesson V., under full control of the bridle as in fig. 3. Compel him to go into every conceivable place. Make him hold his head in every immaginable 
position ; and, if he resists, give him the "controlling touch" as explained in Lesson III. Then handle him head and foot together by passing the leader under his fetlock, drawing his nose down to his foot and making him hold it there. Then pick his hind feet up on the safety-rein, as explained in Lesson V., in "educating a colt to be shod." When he can be handled by the bridle in every respect, then put on the saddle and adjust reins and safety-reins as in fig. 9. Then put him about the stable, rein him about from right to left as in Lesson $\mathrm{X}$. using the whip sufficiently to get plenty of motion. Then compel him to go to the corners and other places by taking position as in fig. 10 and throwing the safety-rein as described in Lesson $\mathbf{X}$., and finally drive him about the floor under the whip, setting heavily back on the reins at the word "whoa" until he is under thorough control and afraid of the bit. If you think he is sufficiently controlled to be safe to drive, take the knots out of the leaders and drive with the reins through the loops as in fig. 12, with the loops buckled well up on the over-draws. When on the road you should set back on the reins occasionally, so as to remind him of your control; keep a careful watch of him, and when he shows a sign of kicking shout "whoa" and set back on the reins, at the same time jerk back hard on the safety-rein, which will throw the bit to the roof of his mouth and control him and will throw his nose into the air and prevent his kicking. It will also be well to check him well up by tightening the thong used as a check in fig. 9. By so doing you will get the bit to act well and keep your control better. If he shouldn't appear safe to drive after the first lesson, give him another and get him under perfect control before you start. If he is under perfect control he won't kick. Drive him constantly with the bridle, being sure to give him a floor lesson each time before driving him until you are sure he will behave.

If the horse kicks because he is afraid of the shafts or any thing that comes against his legs, or because the rein gets under his tail, educate those different parts by repeated handling 
on the floor, with the bridle on for full control as in fig. 3 . Take a pole and play it all about his body and legs. If he objects, control him by touching him over the neck with the rein, and repeat this lesson with the pole until he will stand quietly and allow you to handle it all over his bocly and legs. Then lead him about with the pole between his fore legs and teach him to step over it when he feels it rub his legs. Then do the same with his hind legs by holding the pole in one hand and leading him with the other. Soon you can tie the end of the pole to the breast-plate and let it drag, driving him about with it between his legs. Soon you can take two poles, run one through each thill-lug, let them trail along the floor and drive him about the stable and yard. In this way you can educate him so he will become perfectly indifferent to anything striking his hecls and will stand it all good-naturedly. When he shows that he is educated, drive him, and not before, for you are risking too much to run chances. You can better afford to give him three lessons too many, than one too few. A kicking horse can be driven withont his kicking, by tieing a stout piece of cord tightly around the tail, under the hair just below the root of the tail before driving out. This method is a preventive only; for he will kick as bad when the cord is removed. It is with a kicker as it is with every other vice: simply a matter of education. The kicker can be treated by the Rarey system of subduing, be inspired with fear of his trainer and he will not kick while that man drives him. But when he is driven by another, his desire to kick not being eradicated, he will acquire the habit again. This method will make a permanent cure of the habit, because it is controlling, instead of subduing, and it removes the desire by the process of education.

Of course it is understood that, in speaking of educating horses, of whaterer fault, horses with no intelligence, such as "dummies" and "lunkheads" are not included; for the word " educate" can only apply in a case where there is something in the form of brains to work on. The horse with no intelligence must be appealed to through his body by the infliction 
of pain, and as that requires harsh treatment, no directions for handling such cases will be found in these pages.

It may also be said that there are incorrigibles among horses as well as men, and that it is an impossibility to reclaim some of them from their vicious tendencies; but it does not follow that these same horses, if properly trained when young, would still have been vicious. Old and vicious stallions of combative and courageons dispositions, that, when they first broke away from control were whipped and clubbed by their ignorant trainers until they considered man their natural enemy, but, in the contest of brute force against brute force have been victorious every time, can be said to be irreclaimable, as the passion induced by the approach of man amounts to madness. Such horses have been, and can be, subdued and rendered docile for the time being, but there is no record of their ever having been permanently cured of their viciousness and made safe for any ordinary horseman to handle.

Old and vicious kickers and balkers, also, may be classed among those that cannot be reclaimed. If they had been intelligently handled when they first acquired the fault, no doubt they would have become serviceable animals. But they have been fought with and tortured by their brutal drivers so long, that they mistrust and hate man on general principles; and their faults have become so firmly seated that their increased value would not recompense for the time and trouble of handling them.

So the most that can be done, then, is to let this class of horses pass away, and do our duty by educating the coming generations of colts so that they will develop no bad habits. This will not be a difficult matter if farmers, and others who a:e growing colts, will inform themselves in methods of training that are calculated to produce the best results in the education of their colts. Having a method of perfect control and following a complete system in educating, in connection with the high clegree of intelligence that the well-bred colts of to-day possess, will surely result in untold benefits to the horsemen and bring the education of the future horse to a state of perfection. 


\section{CONCLUSION.}

An examination of bits of ancient construction will show that, ages ago, horsemen were possessed of the knowledge, that a slight pressure brought to bear in the centre of the roof of a horse's mouth would have a wonderfully controlling effect upon the animal and render him docile. They constructed their bits in such a manner, by elevating the centre, that with a slight pressure on the rein, the centre of the bit would press against the roof of the mouth and bring the horse under control. The slight construction of their bridle and reins made it impossible for them to make the bit an implement of torture, and rendered it necessary for them to handle their horses with a delicate touch else they would lose their control by breaking the rein. Nor was it necessary for them to use a great amount of strength in order to obtain control, for the spot upon which they controlled was very sensitive, and required but a gentle pressure upon it in order to bring the animal's attention to business. It is positive, then, that they well knew the existence of this controlling spot in the horse's mouth; and this fact, in connection with the supposition that a wise Creator would, in designing a powerful animal for man's use, provide a means by which its powers could be controlled and made useful, would lead us to believe that the ancients controlled their horses as was intended they should be controlled. But when we came to use the modern leather reins in connection with that bit, the strength of the reins made it possible to make the bit a harsh appliance in the horse's month; hence its gradual alteration, until now we have a bit that cannot be made cruel with anything like moderate usage. 
A study of the anatomy of a horse's head, especially that pari pertaining to the nerves, will demonstrate that there is a nerve, termed the "superior maxillary nerve," running from the roof of the mouth to the brain of the horse; and the end of this nerve was the point reached by the older forms of bits. By the use of a Wilson, four-ring, double-joint bit, in connection with a bridle constructed like the one in fig. 2 , and by properly arranging and handling the reins, as explained in the several lessons in this book, we get the same control as was obtained by the ancient bits, by causing the center of the joint-bit to press against the end of this nerve, where it terminates in the membrane of the roof of the mouth. Those who have practiced this system of control can testify, that not only is the influence of a pressure on this nerve controlling, but it is also soothing, and tends to remove the nervousness and irritability of the horse : two results which are most to be desired while we are endearoring to educate him, for then we are enabled to keep his mind calm and in a condition which will enable us to make a permanent impression as each lesson is given.

It will be seen that the system of educating colts and horses, as given in this book, is much the same as that applied in the education of a child. We begin by teaching him the rudiments first, and laying a foundation upon which to build; then, by adding one lesson after another, we finally reach that stage in his education which simply amounts to perfection, and we have an animal that is a credit both to himself and his trainer.

\section{"A BAD PENNY ALWAYS RETURNS," BUT A LOANED} BOOK SELDOM DOES.

If your "cute" neighbor, who is always depending on other's to supply him with valuable information, while he keeps his own dollars tied up in the toe of his stocking, asks you to lend him your book, tell him where he can buy one, and keep your book in your own possession. In doing so, you show your own wisdom and a desire to benefit the one to whom you are indebted for 
furnishing a valuable work at so little expense ; besides which, a book containing information of this character should be held as a legacy to your sons, to benefit them in years to come. If it is lost they will be deprived of that which would be of great. value to them.

\section{THE TREATMENT OF DISEASES.}

Every man who ever wrote a book on horse-training, has culled a lot of recipes and formulas for the treatment of diseases from various sources, and printed them in his book to offset. weak points in his work, and make people believe they were getting the worth of their money ; and, in so doing, they committed a grave error in assuming knowledge concerning matters of which they were ignorant, worked incalculable damage to those who trusted to their knowledge, and defrauded the public by obtaining money for a lot of worthless matter. The possession of these recipes has worked more harm than good to the owners of horses who were unskilled in the location and treatment of diseases, for the remedies were invariably misapplied. While the administration of a good remedy, according to the directions contained in the recipe, might accidentally be adapted to the disease and condition of the horse at the time of treatment, in the majority of cases the location of the trouble can be determined by a skillful practitioner only, and the stage of the disease and condition of the animal might demand a radical change in any prescribed treatment.

Such being the case, I abstain from printing any recipes in this work, and content myself with treating on the education of the horse : a subject on which I have often been asked to write. My advice would be to consult a competent veterinarian, and not assume responsibility where a slight mistake would be fatal in its consequences; and, in giving this advice, I think I am conferring a greater benefit on my readers than I would were I to publish all the recipes and formulas in existence. 


\section{TESTIMONIALS.}

Having been repeatedly requested by hundreds of horsemen, to whom I liave taught this system of educating colts and unruly horses, to publish this system in book form, so that it would reach the multitude and benefit the coming generations of horsemen, I have written and arranged the foregoing pages, as best I could, in order to gratify those requests. Many men have said to me: "Professor, a general introduction of your system is of so much importance to horsemen, and of such rast benefit to the interests of the horse from a humanitarian standpoint, that you ought not to come to our town, stay a few days only, teach the system to a limited number and then depart; but you should stay longer, until every man who owns a horse has received your instructions." Stimulated by such remarks, I often appointed dates for another course of lectures and frequently formed larger classes than on my first visit. But the introduction of the system was necessarily limited by that method, and it could be generally introduced only through the medium of a book, in which every step taken in the process of educating the colt and horse, is thoroughly explained and illustrated as it is in this work.

I am aware that several books, treating on the education of the horse have been published; and while these books have their merits, the methods taught by them are too harsh to meet with the approval of those who have the welfare of the horse at heart, are too complicated and impractical, and the greatest objection is, that they treat on the subject in too general a manner and do not go into details : attention to which is most important in the prosecution of any undertaking.

In this book I have started with the sucking colt and followed him in his education, from the time he is first approached 
by man, until he is well educated, "waywise" and a good ribbon-roiner." I have arranged each lesson in its order as it should be applied, shown what should be done first, second and last, and have taken especial pains in each lesson, to describe and illustrate the process by which his education may be perfected in the shortest possible time. I have also treated on the unruly habits of horses and minutely described a method by which they may be educated ont of their fanlts without brutal treatment and by the use of the bridle and reins only. Asicle from this, I have given in this book numberless valuable hints concerning the management and care of colts and horses, a study and practice of which will elevate the horse to his proper place in man's estimation, render his existence more endurable and make him a more serviceable animal.

The system of controlling and educating colts and horses explained in this book is entirely new and has never before appeared in print. The matter regarding the education of colts and horses is not the cullings from any other book or books, but is the result of my own thoughts without reference to any other authority; consequently the ideas are new and up to the times.

The following testimonials from practical horsemen, in regard to my method of educating colts and horses, will show that this book is well calculated to meet the wants of farmers, horsemen, and men in every walk of life who wish to perfect themselves in knowledge pertaining to the horse and his education :-

$$
\left.\begin{array}{r}
\text { Office of Geo. H. Bailey, D. Y. S., } \\
\text { Pnrtland, Me., April } 8,1886 .
\end{array}\right\}
$$

To Whom It May Concern :-

Having had occasion to look into the system of educating horses as practiced by Prof. W. H. Sanborn, I am convinced he has originated a safe, simple and practical method of controlling the most vicious and unruly horse or colt. There is more in his system to approve, and less to condemn than in any other that has come to my notice.

$$
\text { Geo. H. Bailey, V. S. }
$$


Portland, Me., March 30th, 1886.

Other men have preceded Professor Sanborn; but it has remained for him to teach a perfect system of control, without torture, which will apply to every horse irrespective of fault or disposition. He uses nothing but a bridle, reins and joint bit to control and handle colts and horses of whatever fault, and he obtains the most satisfactory results without the least harshness or pain to the animal. In fact, his system is a revelation to horsemen; making it easy for them to accomplish feats heretofore considered impossible, viz. : controlling bolters and shyers and driving timid horses to locomotives, umbrellas, etc. The most commendable features of his system are its utility, practicability, and the ease with which it can be put into use by others. We cordially recommend the Professor and his system to all who are interested in the humane treatment of horses and colts.

Chas. Mclaughlin,

H. Richardson, V. S.,

E. MAXWELL, V.S.,

W. H. SNell,

WhitMan SAWYer,

E. W. Hunt,
Geo. H. Bailey, V. S.,

F. W. Huntington, V. S.,

A. G. SAWYER,

F. C. Hayes,

A. M. Sawyer, S. P. C. A.,

S. Porter, and others.

Yesterday afternoon at the livery stable of F. C. Hayes on Plum Street, about twenty gentlemen, including some of Portland's leading horsemen witnessed an exhibition of Prof. W. H. Sauborn's system of controlling and educating horses. Mrr. Sanborn is from Rochester, New York, and has been in this State for some time teaching his system. The method relies solely upon the use of the bit and bridle, and is calculated to meet with approval from every one anxious for the introduction of scientific and humane methods in the handling of horses.

A horse belonging to Mr. A. M. Austin was placed under Mr. Sanborn's care yesterday afternoon. It has been almost impossible in the past to bridle the animal, but in a few moments this was done and the horse became as quiet and tractable as could be wished. The gentlemen present testified to their pleasure at the result of the exhibition.-Portland Press, March 31, 1886.

Saturday forenoon, Professor Sanborn took a mare belonging to Joseph A. Kendall, handled her a few minutes before Mr. Kendall, Dr. Richardson and some others, then drove her to 
the P. and R. depot, where she coolly and repeatedly put her nose against the locomotive and stood in the steam without showing fear, which was witnessed by quite a crowd. The Professor obtains control by the use of bridle and reins only, and assures us he can impart his method to others. It would be valuable imformation to every horseman. He has several other timid horses to educate this week. Those who own unruly horses should call on him. He evidently understands his businéss._Portland Me., Press, April 5, 1886.

"His twenty-seven pupils here will always testify to his great skill as an educator of the horse and colt." -Lincoln County News.

"Professor W. H. Sanborn created a good impression here. His system of educating horses and colts is bighly spoken of by our horsemen.-Rockland Opinion.

"Professor Sanborn, by his remarkable performances in controlling bolter's, kickers, runaways, horses afraid of cars, etc., in this State, has gained a reputation equalled by no other man. His lectures here were interesting and full of new, common sense and practical ideas concerning the management and education of the colt, and those who attended feel well repaid."-Norway, Me., Advertiser.

"The class of Prof. W. H. Sanborn are each and all enthusiastic over his system and teachings, and are thoroughly satisfied that he has fully solved the problem of controlling the horse from a humanitarian standpoint ; all his methods accomplishing complete and satisfactory results without any species of torture. The breaking of a surly, wilful, chronic bolter, and training a horse afraid of smoke to walk up and eat of smoking straw, were among the interesting and fun-provoking incidents."-Bridgton, Me., News.

"A horse always in dread of an umbrella, was driven right up to one spread, and exhibited no fear when it was handled all over her, and this on the street, too."-Brunswick, ile., Telegraph.

"Professor Sanborn, the noted horse trainer, has been at Frankfort breaking the famous colt, "Kentucky Wonder," he having become vicious in harness. The Professor had him 
under control in three days, so that now a lady can haruess and drive him."-Maine Furmer.

\section{Office of J. L. Horr, M. D., Saccarappa, Me., April 24, 1886 .}

During the present week we have had the pleasure of witnessing an exhibition of Prof. IV. H. Sanborn's system of controlling and educating horses and colts. His methol of training is truly wonderful and his success astonishing. He took a mare of mine that I could not drive near a train of cars, and in a short time could drive her close to a steaming locomotive. She drives so much better since his training her that I consider her worth twenty-five dollars more than before.

J. L. Horr, MI. D.

Saccarappa, Me., April 27, 1886.

I own a mare that was very afraid of a locomotive, and she would rear, plunge and run back whenever I tried to near it. Professor Sanborn handled her April 20, for about five minutes, before myself and several others, and with the use of nothing but bridle and reins, without throwing, whirling or whipping, he then drove her close to a steaming locomotive where she stood still. I can now drive her there myself as vell as the Professor can.

C. J. Schwartz, Liveryman.

Prof. W. H. Sanborx.

Webster, Me., April 11, 1886.

Dear Sir:-Since you used your method of controlling horses, last November, on my stallion, "Gen. Shields," he has been as clever as any horse can be, and I can now lead him out for service with perfect safety. He is also clever in the stall and has not offered to bite or strike. Before you came to Sabattus he was entirely unmanageable, was feared by every one who came in contact with him, and was considered by practical hcrsemen to be a dangerous horse.

D. S. Halasy.

WArres, Me., July 18th, 1885.

Professor Sanborn handled a very wilful bolting colt for me, that had defied all my efforts to rein her, and controlled her so effectually, that he drove her to objects to which, before he handled her, it was impossible to drive her, and I can now drive her as well as he can.

C. S. Coburn. 
Washivgton, Me., Aug. 3il, 1885.

For handling colts, halter puller's and other rices, all of which Professor Sanborn treats, he is the most successful educator I have ever seen or heard of; and I am pleased to recommend him, not only as an efficient educator of the horse, but as a pleasant and agreeable gentleman. His system can as well be taught by any of his pupils as by himself.

Hiram Beiss, Jr.

Freedou, Me., Sept. 17th, 1885.

My stallion, "Pompeii," was very unruly on the road or track, it being impossible to speed him without his breaking and running. I drove him but three hour's under Prof. Sanborn's system, and I can now control him with ease.

Chesley B. Ingrailair, Knox, Me.

Buckfield, ME., March 9th, 1886.

Your system is superior to anything I ever saw. It broke my bolting horse at once so that a boy can drive him.

David Recorid.

North Axson, Me., March 3d, 1886.

I have handled your way and think it is the best thing I ever saw. It is worth all it costs to teach a colt how to back. The black mare you bandled is all right.

\section{B. B. Phillips, Trainer of Colts and Trotters.}

\section{Jeffersox, Me., March 5th, 1886.}

In regard to the bolting colt you handled last August, you did him more good, what little you handled him, than Kieiser (an old colt trainer) did in five weeks. You broke him of his shyness and reined him well.

Lorexzo A. Meservey.

\section{Waldoboro, ME., March 8th, 1886.}

It gives me pleasure to say that your system has been a great benefit to me in handling my colt, as it only required a few days to break him.

II. R. ACHORN.

$$
\text { Uniox, Me., July 28th, } 1885 .
$$

Professor Sanborn's system of controlling and treating vicious horses and colts gave perfect satisfaction to his class here. J. W. Burrows \& Sor. 


\section{Presque Isle, Me., May 9, 1885.}

Professor Sanborn's system is easily learned and applied, and gives immediate control. He obtained such complete control over two vicious kicking mares, in a few minutes, before the class, that he haruessed and unharuessed them with ease.D. F. Dyer, Fred Davis, J. H. Currier, S. W. Duff, Geo. Goshine, W. H. Worthley, F. E. Branion, Geo. F. WhitNey, and others.

\section{Bridgewater, Me., May 5th, 1885.}

I believe Professor Sanborn's system of handling horses and colts, to be the only true system.

HoN. J. H. KIDdER.

\section{Warren, Me., July 18, 1885.}

We are convinced that Professor Sanborn has solved the problem : how to control and educate colts and unruly horses without harshness. He uses nothing but a bridle and reins, and discards the whip, throwing and whirling as a means of control. The results are speedy, certain and permanent. Those who have colts to handle can, by his system, save time and labor, and produce better educated colts in a few days than in weeks by any other method. He handled a bad bolter, one nettlesome about standing, and a horse contrary in backing, while here, to the satisfaction of all.-H. C. KaLlOCH, J. W. Eastman, Daniel Ladd, M. D. Watts, C. Peabody, L. MI. Newcomb, Ellis Watts, C. S. Rice, D. E. Fiske, C. S. Coburn, W. R. Feyler, Nathaniel Eastuan.

\section{Thomaston, Me., March 8th, 1886.}

My experience as a practical horse shoer during a period of some thirty years, including three years among the Cavalry of the U. S. Army, has brought me in contact with an unlimited number of the most vicious horses and mules. I regard the system as taught and practiced by Prof. Sanborn, for shoeing and managing vicious horses, also breaking colts, the most successful and complete that has yet come under my observation.

E. C. Andrews, Practical Horse Shoer.

Patten, Me., June, 1885.

The Professor handled my three year old stallion, not thoroughly controlled and unruly in stud, to my satisfaction. L. II. Grant. 
Bethel, MIE., March 4th, 1886.

I have attended all the horse trainers' schools that have been in Bethel for the last twenty years and have practiced their methods. I cheerfully recommend Professor Sanborn's method as the best for shoeing colts and bad horses.

J. C. Billivgs, Practical Horse Shoer.

Montrille, Mie., Sept. 27th, 1885.

Last Angust 10th, Prof. Sauborn directed me how to handle a vicious kicker. I followed his directions, and after twentyfour hours it was impossible to make him kick.

Nelson Young.

East Vassalboro, Me., March 4 th, 1886.

I am glad to inform you that the runaway colt you handled last Sept. 1st, is doing nicely and drives as well as any horse. John Getchell.

Jeffersox, Me., March 12th, 1886.

I have had good success with your method of handling colts. I think it is the most practical way to get them under control. Thos. P. Weeks, Colt Trainer.

Dixfield, Me., March Tth, 1886.

I have had the best of success with your system of handling, and should not want to get along without it. E. O. Aues.

\section{Socth Paris, Me., March 8th, 1886.}

Within the past year I have broke some forty colts and horses, and have in every case used your system, and have invariably found it equal to the occasion. Some of the horses handled have been vicious, but in no instance have I failed to make them do what I asked of them. I consider your system of controlling and breaking colts the best I have seen. I have tried several others, but the one taught by you is unquestionably the best, and I would not part with it for any consideration.

Frask L. Starbird, Colt Trainer.

North Lnios, Me., March 15th, 1886.

I have trained colts for twenty-five rears, but your way is easier than anything I have ever found. It has done me a great deal of good.

Daxiel. Hubberd, Colt Trainer. 


$$
\text { JAY, ME., March 14th, } 188 \mathrm{C} \text {. }
$$

My colt drices quite well now. He was not safe to drive before I took him to you last December. E. W. Gould.

\section{Glex House, N. H., March 4th, 1886.}

I have used your method of treating lickers and switchers with good success, and your method of breaking colts is the best I ever used.

J. W. Brown.

Frankfort, Me., Nov. 20, 188 j.

"Kentucky Wonder" was harnessed a few times last winter, but after a short time he became very vicious in harness. Professor Sanborn handled him from Oct. 15th to 17th, and I now consider him safe for my wife to drive.

Rowe EMery.

\section{Fryeburg, Me., March 3d., 1886.}

This certifies that my mare was afraid of the cars ; but after a few minutes' handling before the class, Prof. Sanborn drove her to a locomotive without her showing the least fear.

\section{A. P. Charles.}

Witnessed by F. W. Spring, James G. Hill, W. R. Tarbox.

$$
\text { North Axson, Me., Dec. 17th, } 188 \tilde{\text { J. }}
$$

Prof. Sanborn can, and does, do all he claims.

$$
\text { J. B. TwaddLE, M. D. }
$$

Bridgtox, Me., Feb. 8th, 1886.

We candidly think that every man, especially those who are growing colts, would be benefitted by Professor Sanborn's system. His method is entirely new, without torture, and can be used by others with success, as he uses nothing but bridle and reins to control and handle. - Rev. T. M. Davies, S. S. FulLer, R. A. Hil.L, G. L. Robinson, E. Waterhouse, W. M. Staples, and others. 



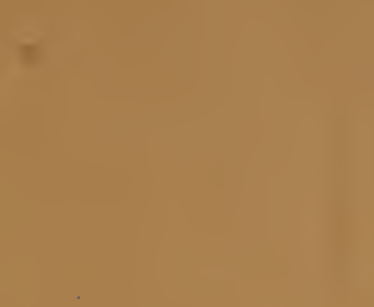

\section{7}

ating

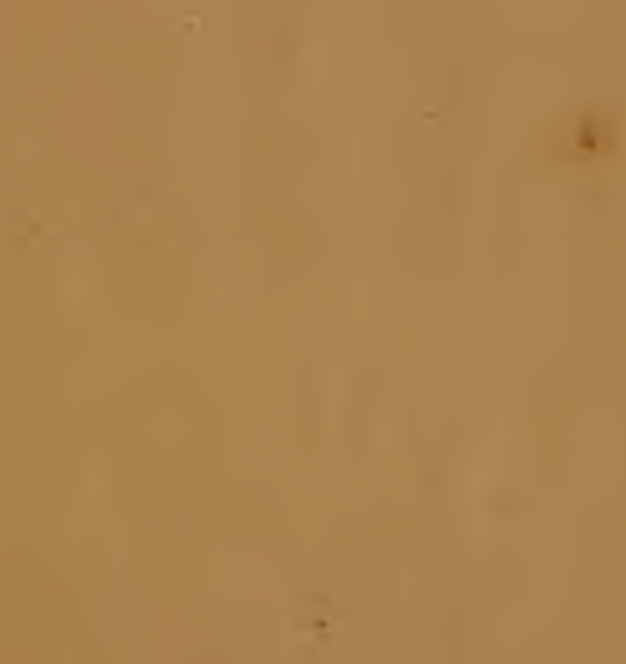

int 


\section{Prof, W, H, SANBORN'S Improved Controlling Bits,}
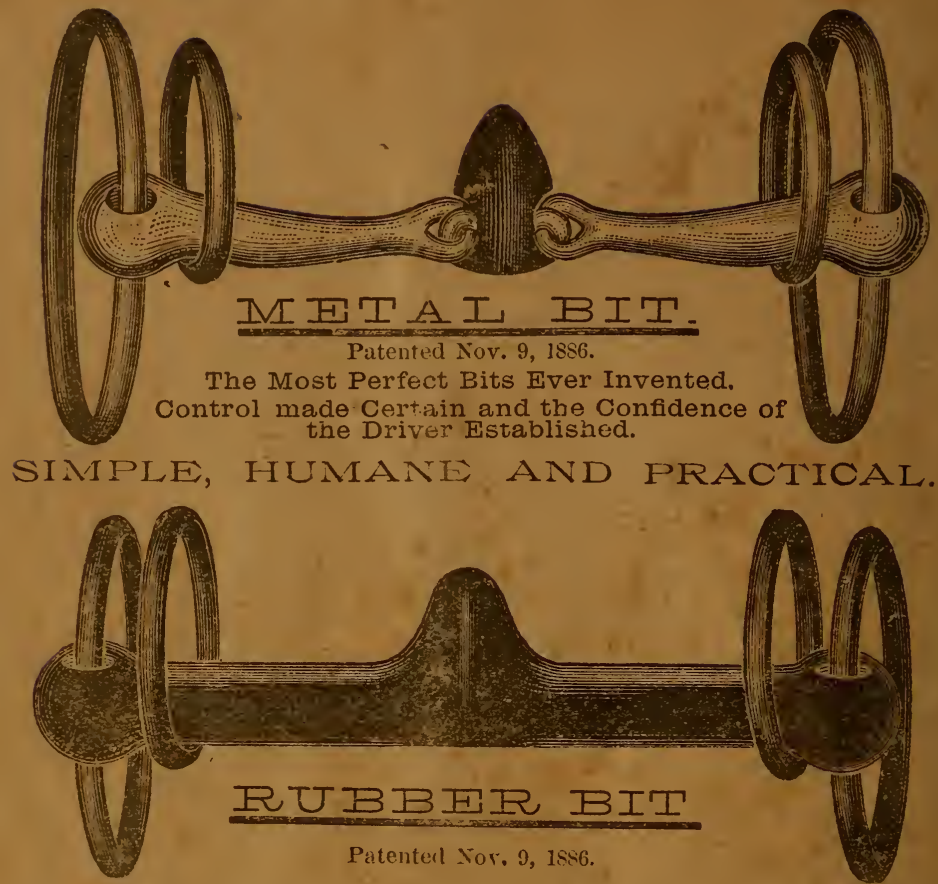

It is an establisher fact that the more sensitive place we can find upon which to control, the finer the control will be. The most sensitive place aliout the horse is the center of the roof of his mouth, liack of the fifth bar. A slight pressure on chis place with the ent of the thumb will enntrol tor a variety of purposes. This prinei. ple is brought intu practical operation by my patent bits, which will gire the most satisfactorry control ever obtained.

The mijority of lorses have the roof's of their moutlis more or less concave; and the protuberance on the centre of my bits fits into the earity, helps holn the lit

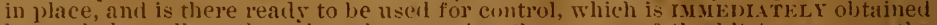
by a slight pull on the reins, thus causing the centre of the bit to press on the "CONTROLliNG NeRTE."

For very rank and heallstrong horses, the meTAL BIT should be use.t. For those that aie sensitive and of nerrons disposition the Rr:BBER BIT will answr.t.

The above bits can be used in commection with a bricle constracted as in Fig :2, in this book; or for ordinary driving purposes they may be used in connection with an orerdraw, with nose-band attiched to the inner rings.

C'sed as described, they will be fomml to be a sure cure for lonting, pulling, side reining, slyving lolling, iighting eleck, pnor reiners; and itsed in ennnection with a brille like nine, as ill:1striterl on page 3.j, will prevent a trotter from breaking.

Ifsirirs. Craxe d Co., Newark, I. J., have the exclusive license to manufacture these lits.

The metal bits are forged from liest quality of steel. The rubber bits are male of very stromg, tiexible steel rhitin, eovered with hest ruality of rubber. used for such purpuses. Every bit is thoroughly tested before learing the factory.

For sale by saddlers generally, or by me at my Lxhibitions. 